\title{
THE GOVERNANCE OF HUMAN (GERMLINE) GENOME MODIFICATION AT THE INTERNATIONAL AND TRANSNATIONAL LEVEL
}

\author{
Cesare P.R. Romano, Andrea Boggio, Jessica Almqvist
}

\begin{abstract}
This is an excerpt from Andrea Boggio, Cesare P.R. Romano, Jessica Almqvist (eds.), Human Germline Genome Modification and the Right to Science: A Comparative Study of National Laws and Policies, Cambridge University Press, 2019. It is the version sent to the publisher, before editing. Please, cite to the published book. This chapter discusses the present international and transnational regulatory framework of the modification of the human genome in general, and, when applicable, of germline cells. It includes a discussion of applicable standards of International Bioethics Law and International Human Rights Law, as well as a primer on basic notions of International Law and International Human Rights Law.
\end{abstract}

\section{Table of Contents}

I) KEY TERMS AND A QUICK PRIMER OF INTERNATIONAL LAW AND

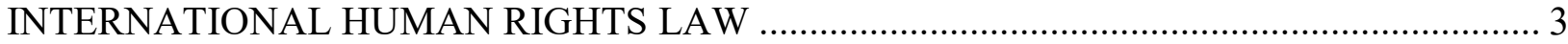

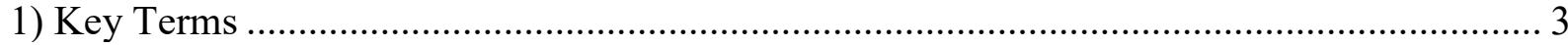

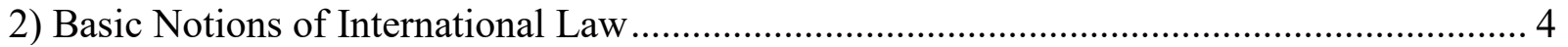

3) Basic Notions of International Human Rights Law....................................................... 7

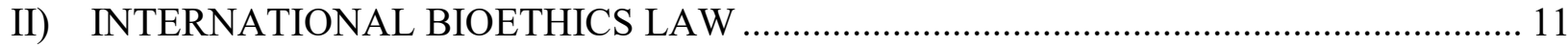

1) UNESCO .

a) UNESCO Universal Declaration on Human Genome and Human Rights (1997).... 14

b) UNESCO International Declaration on Human Genetic Data (2003)....................... 20

c) UNESCO Universal Declaration on Bioethics and Human Rights (2005) ................. 23

d) Overall assessment of the work of UNESCO and future developments ..........................2 25

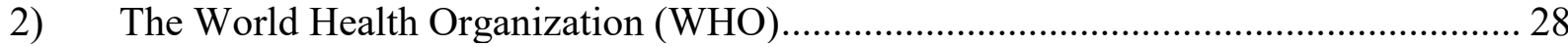

3) The Organisation for Economic Co-operation and Development (OECD) …………..... 31

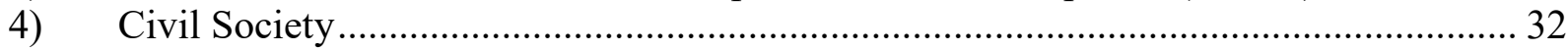

III) APPLICABLE INTERNATIONAL HUMAN RIGHTS STANDARDS ………............. 35

1) The Right to Science and the Rights of Science: Origin and Development. .................. 36

2) From the Vanishing Point of International Human Rights Law to Front and Center .... 40

3) Limits to the Right to Science and the Rights of Science .............................................. 45

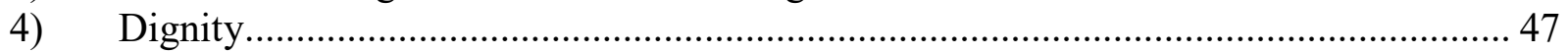

5) A Synthesis of Human Rights Principles Applicable to the Scientific Enterprise. ............... 55

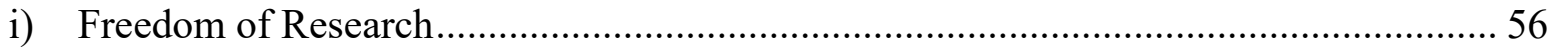

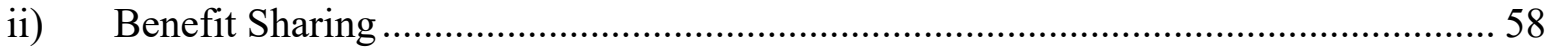

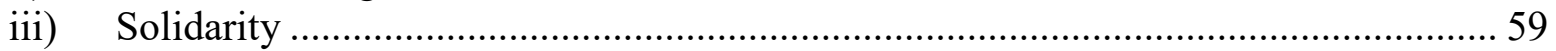

iv) Respect for Human Dignity............................................................................... 60

v) Obligation to Respect and to Protect the Rights and Individual Freedoms of Others 61

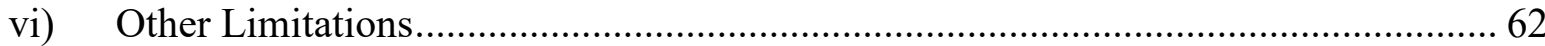

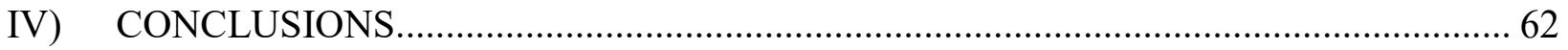




\title{
THE GOVERNANCE OF HUMAN (GERMLINE) GENOME MODIFICATION AT THE INTERNATIONAL AND TRANSNATIONAL LEVEL
}

\author{
Cesare Romano, ${ }^{*}$ Andrea Boggio, ${ }^{* *}$ Jessica Almqvist ${ }^{* * *}$
}

The core of this book is a discussion of how human germline genome modification is currently regulated at the national level in a selected number of states. However, national regulations can be properly understood and assessed only keeping in mind the larger international and transnational framework within which these national legal regimes exist. Although bioethics and international human rights law were born out of the same horrors of the Second World War, for most of the remaining part of the twentieth century they developed in parallel without significant crossovers. Human genome modification has traditionally been discussed under the heading 'bioethics', using its concepts, terminology and discourse. However, at the beginning of the twenty-first century bioethics and human genome modification started being discussed within the wider international human rights framework and the even wider international law framework.

Before discussing international norms and the legal instruments that contain them, for the benefit of those readers who are not familiar with international law and relations, its concepts and terminology, we will introduce in Part I some key terms and a quick primer to international law and international human rights. Those who are already familiar with them, should skip directly to Part II, where the relevant norms of international bioethics law are discussed. Part III, discusses international human standards that are most relevant for a discussion of human germline genome modification, and in particular the so-called 'right to science' and the so-called 'rights of science'. Finally, in Part IV we discuss how these rights can contribute to the emerging international regulatory framework. In particular, we will highlight five key principles associated with the 'right to science' and the 'rights of science' and their connection to the other international instruments

\footnotetext{
* Professor of Law, W. Joseph Ford Fellow, and Director of the International Human Rights Clinic, Loyola Law School, Los Angeles.

** Professor of Legal Studies, Bryant University.

*** Associate Professor of Public International Law, Law Faculty, Autonóma University in Madrid.
} 
Pre-editing version of the corresponding chapter in Andrea Boggio, Cesare P.R. Romano, Jessica Almqvist (eds.), Human Germline Genome Modification and the Right to Science: A Comparative Study of National Laws and Policies, Cambridge University Press, 2019 (ISBN: 9781108499873)

we have reviewed in this chapter: freedom of research; benefit sharing; solidarity; respect for human dignity; and respect of the human rights of others.

I) KEY TERMS AND A QUICK PRIMER OF INTERNATIONAL LAW AND INTERNATIONAL HUMAN RIGHTS LAW

\section{1) Key Terms}

Throughout this volume terms such as 'international', 'transnational', 'supranational', 'multinational', 'regional' and 'global' are used. They are not synonyms. Each has a specific meaning. 'International' refers to relations between sovereign states and the laws regulating their interactions (mostly but not exclusively). 'Transnational' refers to relations across national borders between non-governmental actors. 'Supranational' refers to a phenomenon whereby several states have transferred part of their sovereignty to common international institutions. The difference between 'international' and 'supranational' is a matter of degree of transfer of sovereignty, with 'supranational' defining legal phenomena in which the transfer of sovereignty is greater. 'Multinational' is used to indicate an organization, often a corporation, operating in multiple sovereign states at once. Finally, the term 'global' indicates a phenomenon that occurs in multiple states, on multiple continents at once, while the term 'regional' is used to refer to a phenomenon that occurs only in a portion of a globe (e.g., the European Union, or the African continent).

We also speak of 'governance' and 'regime'. The term 'regime' describes not only a set of norms focusing on a given subject-matter but also the decision-making machinery to create, update and enforce them. ${ }^{1}$ Thus, the international legal regime regulating human germline genome modification comprises both norms and the institutions that articulate them. In a very broad sense, 'governance' is the 'act of governing' or administering a community or an issue. More specifically, it is used to indicate the processes of interaction and decision-making among the actors involved

\footnotetext{
${ }^{1}$ S Krasner (ed), International Regimes (Cornell University Press 1983).
} 
Pre-editing version of the corresponding chapter in Andrea Boggio, Cesare P.R. Romano, Jessica Almqvist (eds.), Human Germline Genome Modification and the Right to Science: A Comparative Study of National Laws and Policies, Cambridge University Press, 2019 (ISBN: 9781108499873)

in a collective problem that lead to the creation, reinforcement, or reproduction of both norms and institutions. $^{2}$

\section{2) Basic Notions of International Law}

International law is the set of norms that regulates the life of the so-called 'international community'. This community is composed mainly of sovereign states, but it includes also international organizations (i.e. associations of sovereign states created to pursue together some shared goals), natural persons (i.e. individuals), and legal persons, that is to say organizations sharing a common goal (when they are not-for-profit, they are called 'non-governmental organizations' (NGOs); if their purpose is profit, they are 'corporations').

Although international law was initially born to regulate relations between sovereign states only, towards the second half of the nineteen century, international organizations having a legal personality separate from that of their members started appearing. As a result, international law evolved to include the regulation of these organizations as well as their relationship to sovereign states. Later, in the wake of the Second World War, states realized that the protection of individuals could not depend on their citizenship of a certain country but instead had to be based on their status as humans. Indeed, the task of protecting human rights could not be left to the country of nationality only, especially since too often the source of the threat to individual rights and liberties was exactly the person's own government. This led to the adoption of a special set of international norms, called 'international human rights', whereby states recognize a set of basic rights to be enjoyed by everyone, without any discrimination.

International law has three main sources, of which two are arguably the most important: ${ }^{3}$ The first one is 'treaties', which are written agreements concluded between two or more sovereign

\footnotetext{
2 John Gerard Ruggie defined 'governance' as “systems of authoritative norms, rules, institutions, and practices by means of which any collectivity, from the local to the global, manages its common affairs". J Ruggie, 'Global Governance and "New Governance Theory”: Lessons from Business and Human Rights' (2014) 20 Global Governance5.

${ }^{3}$ Article 38 of the Statute of the International Court of Justice is regarded as a codification of the sources of international law. It reads: "1. The Court, whose function is to decide in accordance with international law such disputes as are submitted to it, shall apply: a. international conventions, whether general or particular, establishing
} 
states with the intent to create legal obligations between the parties. ${ }^{4}$ Some treaties are bilateral and function like 'contracts', creating mirror-like, tit-for-tat, obligations. By and large, the legal concepts applying to contracts domestically apply also to treaties. However, some treaties are multilateral and more akin to 'constitutions': they create a structure and a process to create new international law. The Covenant on Economic, Social and Cultural Rights, where the right to science is codified, is an example. ${ }^{5}$

The second source is 'customary international law'. Customary international law is the tradition of the 'international community'. ${ }^{6}$ It is what most states do, or do not do, most of the time. International legal scholars identify two components of this custom: 'practice' and 'opinio juris'. Practice is the objective element. It is what states do and do not do, say or do not say. To find it, one looks at the way states behave every day, on any given topic. National laws, decisions, orders, actions, public statements and the like are all things international legal scholars peruse to determine what the prevailing practice of the international community is on any given subject. Then there is 'opinio juris', which is Latin for 'the opinion of what the law is'. This is the subjective element of custom. It is what states think their legal obligations are. To find the subjective element, one looks at the same documents one looks at to find practice but tries to go deeper and determine whether states follow a certain practice out of a sense of legal duty as opposed to courtesy, convenience, or expediency. The subjective element of custom is present only when a practice is based on a sense of legal duty.

The key difference between treaties and customary international law is that treaties bind only those states or international organizations that ratified them. As a general rule, they do not

\footnotetext{
rules expressly recognized by the contesting states; $b$. international custom, as evidence of a general practice accepted as law; c. the general principles of law recognized by civilized nations; d. ... judicial decisions and the teachings of the most highly qualified publicists of the various nations, as subsidiary means for the determination of rules of law".

${ }^{4}$ Vienna Convention on the Law of Treaties, 1155 UNTS 331, art 2.1.a ""Treaty" means an international agreement concluded between States in written form and governed by international law, whether embodied in a single instrument or in two or more related instruments and whatever its particular designation".

${ }^{5}$ See, in this chapter, Sections III.1 and 2.

${ }^{6}$ On customary international law, see, in general, T Treves, 'Customary International Law' (Max Planck Encyclopedia of Public International Law, last updated November 2006).
} 
Pre-editing version of the corresponding chapter in Andrea Boggio, Cesare P.R. Romano, Jessica Almqvist (eds.), Human Germline Genome Modification and the Right to Science: A Comparative Study of National Laws and Policies, Cambridge University Press, 2019 (ISBN: 9781108499873)

bind third parties (pacta tertiis nec nocent neque prosunt). ${ }^{7}$ Conversely, customary international law binds all members of the 'international community'. New states, upon creation, inherit the whole body of customary international law obligations created by the international community. There is no opt out, but for the case of the so-called 'persistent objector'. If a state persistently objects to the creation of a norm of customary international law, as it emerges, it might successfully argue the norm does not apply to it. However, the 'persistent objector' is a unicorn in international law. There are very few cases of states that have been able to successfully call themselves out of a new norm of customary international law. It is very costly politically to be the nay-sayer for years and decades. ${ }^{8}$

The third main source of international law, which is less important in practice, is 'general principles of law' common to nations. ${ }^{9}$ These are legal precepts that one can find in the national legal system of most states, such as, for instance, the principle that 'contracts must be respected' (pacta sunt servanda), or 'you cannot try the same person twice for the same crime' (ne bis in idem). However, because these principles tend to be extremely vague, they are rarely invoked when trying to ascertain what international legal obligations exist on any given subject.

Finally, there is a fourth source, one that is not considered officially a source as such, but that plays an important role in the life of the international community: 'soft law'. ${ }^{10}$ The term soft law is used to indicate a very broad and diverse set of standards that are included in documents that are not binding per se. This includes the many 'declarations', 'final acts', 'communiqués' and the like that states often issue, individually or in concert through international organizations. These

\footnotetext{
${ }^{7}$ Vienna Convention on the Law of Treaties (n 4) art 34-38.

${ }^{8}$ It should be noted that, occasionally, principles enshrined in a treaty acquire the status of customary law, and thus become binding on all members of the 'international community', including states or international organizations that have not ratified the treaty. For instance, this is the case of the obligation not to send any person to a country where there is a real risk that he or she may be exposed to arbitrary deprivation of life. See, Human Rights Committee, 'General Comment No 24: Issues relating to reservations made upon ratification or accession to the Covenant or the Optional Protocol is thereto, or in relation to declarations under Article 41 of the Covenant' (1994) UN Doc CCPR/C/21/Rev.1/Add.6, para 8.

${ }^{9}$ See, in general, G Gaja, 'General Principles of Law' (Max Planck Encyclopedia of Public International Law, last updated May 2013).

${ }^{10}$ On soft law, see, in general: D Thürer, 'Soft Law' (Max Planck Encyclopedia of Public International Law, March 2009).
} 
documents are not binding. They are not meant to create immediate obligations for states. However, since customary international law is what most states do most of the time, soft law is a very good place to find out what the prevailing practice and opinio juris are. Soft law documents are, in a sense, customary international law in-the-making. This source of international law is important for the topic of this book because, as we will discuss later in this chapter, various soft law instruments dealing with bioethical issues have been adopted in past decades.

To see how 'soft law' can become 'hard law', let's consider the case of the Universal Declaration of Human Rights (UDHR). ${ }^{11}$ Nowadays, it is considered the keystone of the whole international human rights regime, but it was not always like that. ${ }^{12}$ It was adopted in December 1948 by the General Assembly of the United Nations. Out of 58 members of the UN at that time, 48 voted yes, zero no, eight abstained, and two did not vote. ${ }^{13}$ At adoption, it was a non-binding aspirational document, setting out not a list of obligations but rather a list of what states hoped could become obligations. However, by virtue of its large endorsement within the General Assembly, and because over time states kept on referring back to it, either by incorporating some or the whole of it in their national constitutions and mentioning during discussions at the United Nations, it gradually hardened into customary international law. ${ }^{14}$ Practice, supported by opinio juris, created a new set of norms. What is more, parts of it are even considered 'jus cogens', which is customary international law that cannot be derogated, under any circumstance. ${ }^{15}$ It is the core laws of the 'international community'.

\section{3) Basic Notions of International Human Rights Law}

The Universal Declaration of Human Rights is foundational of international human rights law. Soon after it was adopted in 1948, it became clear that more was needed to provide more robust protection of those rights. Ideally, the answer would have been a treaty that created binding

\footnotetext{
${ }^{11}$ Universal Declaration of Human Rights (adopted 10 December 1948 UNGA Res 217A (III) (UDHR).

12 H Charlesworth, 'Universal Declaration of Human Rights (1948)' (Max Planck Encyclopedia of Public International Law, last updated February 2008).

13 ibid.

14 ibid.

15 J Frowein, ‘Jus Cogens’ (Max Planck Encyclopedia of Public International Law, last updated March 2013).
} 
obligations for states to protect the human rights of those within their jurisdiction. The problem was that by then the Cold War had started and the world had split into two opposing camps, the East and the West, each with very different views about what human rights are and which ones should be given priority. ${ }^{16}$ In a nutshell, the East preached that humans could not be free unless they were equal in wealth, opportunities, and power. The West replied that everyone is equal in individual freedom. The East championed heavy governmental intervention in the life of citizens to provide them 'from cradle to grave' with what they needed. The West believed the government should stay out of the life of its citizens and just ensure them protection and security and leave it to the markets to satisfy their needs and wants.

Thus, when East and West sat down to think about a single human rights treaty to complement the non-binding Universal Declaration, their views started looking irreconcilable. The result was the parallel negotiation of two separate treaties. One, the International Covenant on Civil and Political Rights (ICCPR), put the accent on freedoms, on the duty states to stay out of the life of their citizens, on the harm they should not do to them (e.g. deprive of life, torture, enslave, not give a fair trial, arrest arbitrarily, invade privacy, stifle expression, etc.). ${ }^{17}$ The other, the International Covenant on Economic, Social and Cultural Rights (ICESCR), stressed individual rights and the duty states have to provide for their citizens, the goods they have to give them (e.g. education, work, health, social security, culture, 'adequate conditions of living', etc.). ${ }^{18}$ Both Covenants were adopted in 1967 and, predictably, Western states flocked to ratify the former and shunned the latter, while Eastern states did the opposite.

Although this ideological split eventually lost much of its significance as many Western states adopted a 'welfare state' model and Eastern states gradually eased restrictions to the enjoyment of civil and political freedom in their societies, it is a cleave that endures to this day. For instance, the United States has ratified the Covenant on Civil and Political Rights, but not the

\footnotetext{
${ }^{16}$ See, in general, J L Gaddis, The Cold War: A New History (Penguin 2005).

${ }^{17}$ International Covenant on Civil and Political Rights (adopted 16 December 1966, entered into force 23 March 1976) 999 UNTS 171 (ICCPR).

${ }^{18}$ International Covenant on Economic, Social and Cultural Rights (adopted 16 December 1966, entered into force 3 January 1976) 993 UNTS 3 (ICESCR).
} 
Covenant on Economic, Social and Cultural Rights, while People's Republic of China has ratified the Covenant on Economic, Social and Cultural Rights but not the Covenant on Civil and Political Rights. Most states of the world, however, have ratified both and now, these two treaties, together with the Universal Declaration of Human Rights, are considered to form the so-called 'International Bill of Rights'. ${ }^{19}$ It is not a stretch to say that perhaps the triad has acquired customary international law value, although the devil is in the details.

Indeed, with the exception of jus cogens, there is no hierarchy between international human rights. For instance, the right to freedom of expression is not more important than the right to education. They are obviously linked, as one requires the other. However, there is a fundamental difference between civil and political rights, on the one hand, and economic, social and cultural rights, on the other. Civil and political rights mostly create immediate obligations that must be fulfilled by states here and now (obligations 'of result'). Many of them are binary. Either one is held in slavery or not. Either one is subjected to medical or scientific experimentation with consent or without. It is also easy to hold every state to the same standards, since many of the civil and political rights oblige states not to do something, such as kill or torture. However, because economic, social and cultural rights require states to do something, and the things they must do are often broad in scale and very expensive and states have very different amounts of resources, material and human, the obligation is only 'of means'. That is states must make progress towards fulfilling them, but progress is measured depending on their available national resources. It is more difficult to have a single standard for all. They are rights to be realized 'progressively', and progress is a never-ending process.

Of course, these are broad generalizations. There are civil and political rights that require large expenditure and have the same 'work in progress' nature of economic, social and cultural rights. A fair and efficient judicial system is neither cheap nor can be constructed in a day. ${ }^{20}$ And

\footnotetext{
${ }^{19}$ UN Office of the High Commissioner for Human Rights, 'Fact Sheet No.2 (Rev.1), The International Bill of Human Rights' <www.ohchr.org/Documents/Publications/FactSheet2Rev.1en.pdf> accessed 8 November 2018. ${ }^{20} \mathrm{~S}$ Holmes and C R Sunstein, The Cost of Rights: Why Liberty Depends on Taxes (New York, W.W.W. Norton \& Company Ltd 1999).
} 
Pre-editing version of the corresponding chapter in Andrea Boggio, Cesare P.R. Romano, Jessica Almqvist (eds.), Human Germline Genome Modification and the Right to Science: A Comparative Study of National Laws and Policies, Cambridge University Press, 2019 (ISBN: 9781108499873)

there are economic, social and cultural rights that can be implemented here and now. ${ }^{21}$ Denying someone access to healthcare on discriminatory grounds cannot be justified by scarce national resources. Yet, these are important concepts to keep in mind as we discuss international human standards relating to human germline genome modification.

Globally, states have built the edifice of international rights under the aegis of the United Nations. In parallel fashion, groups of states have reiterated many of those rights or, in certain cases, provided for more or other rights at the regional level to accommodate for social, cultural, historical and political regional circumstances. Thus, five regional human rights systems emerged over time: in Europe (starting early 1950s); in the Americas (starting late 1960s); in Africa (starting in the 1980s); in the Arab world (starting late 1990s to early 2000s); and in South East Asia (2010s). The same structure we find at the global level (a declaration and two key treaties, one on civil and political rights and the other on economic, social and cultural rights) is also found in each of these regional organizations, with some variations to adjust for different timelines and historical, social and political preferences. ${ }^{22}$ As a result, human rights are protected internationally through the United Nations at the global level, and by organizations such as the Council of Europe, the African Union, the Organization of American States, Arab League and the Association of SouthEast Asian Nations (ASEAN) at the regional level. Global and regional regimes overlap significantly, with the various regional regimes reinforcing each other, and together form customary international law.

\footnotetext{
${ }^{21}$ For an analysis of whether the International Covenant on Economic, Social and Cultural Rights creates 'obligations of conduct' and 'obligations of result', see UN Committee on Economic, Social and Cultural Rights, 'General Comment No 3: The Nature of States Parties' Obligations under the Covenant' UN Doc E/1991/23 (art 2, para 1 of the Covenant).

${ }^{22}$ For instance, the human rights system of the Organization of American States features a general declaration (American Declaration of Human Rights), a treaty focusing on civil and political rights (the Inter-American Convention on Human Rights) and another on social, economic and cultural rights (the Protocol of San Salvador). The human rights system of the Council of Europe has no declaration, but two core treaties, one focusing on civil and political rights (the European Convention on Human Rights) and another on social, economic and cultural rights (European Social Charter). The one of the African Union has a treaty focusing on civil and political rights (the Banjul Charter), but no declaration and no treaty focusing on social, economic and cultural rights. The human rights system of the Arab League has a treaty on civil and political rights but no declaration, nor a no treaty focusing on social, economic and cultural rights. Finally, the Association of South East Asian Nations (ASEAN) features a declaration but no treaty yet.
} 
Pre-editing version of the corresponding chapter in Andrea Boggio, Cesare P.R. Romano, Jessica Almqvist (eds.), Human Germline Genome Modification and the Right to Science: A Comparative Study of National Laws and Policies, Cambridge University Press, 2019 (ISBN: 9781108499873)

\section{II) INTERNATIONAL BIOETHICS LAW}

The broader international framework within which the various national governance regimes exist includes both international norms specifically referring to human genome modification, which are part of the corpus of international bioethics law, and international human rights standards. As it was said earlier, human genome modification has traditionally been discussed under the heading 'bioethics', using its concepts, terminology and discourse. However, at the beginning of the twenty-first century bioethics and human genome modification started being discussed within the wider international human rights framework and the even wider international law framework. Thus, first, in this part (II) we will present the relevant international bioethics norms. In the next (III), we will discuss some specific international human rights norms that, we believe, must be taken in consideration when discussing the overall international legal framework for human germline genome modification.

However, before we turn to that we need to make it clear that any attempt to present the legal standards regulating human genome modification in general, and germline genome modification in particular, presents three main challenges that must be addressed. The first one relates to the scope of analysis. Governance of human germline genome modification is a crucial but narrow facet of the larger question of the governance of human genome modification tout court, which, in turn, is a subset of a broader field, international bioethics law, which is itself a specialized branch of international law. A discussion focusing exclusively on the current state of governance of human germline genome modification would be very short and much of it would also be speculative. More importantly, it would fail to take into account all relevant standards that come into play when addressing the question of the governance of germline modification from bench to bedside. Indeed, what the relevant laws and standards are can be properly understood only if they are connected to the broader field of international bioethics law, which is made of hundreds of instruments that have been adopted since the end of the Second World War. ${ }^{23}$

\footnotetext{
${ }^{23}$ For a list of hard law and soft law international bioethical instruments, see: Human Rights Library, 'Bioethics and Human Rights Links' (University of Minnesota) $<$ http://hrlibrary.umn.edu/links/bioethics.html $>$ accessed 7
} 
Pre-editing version of the corresponding chapter in Andrea Boggio, Cesare P.R. Romano, Jessica Almqvist (eds.), Human Germline Genome Modification and the Right to Science: A Comparative Study of National Laws and Policies, Cambridge University Press, 2019 (ISBN: 9781108499873)

The second challenge to our inquiry is the number and nature of the normative instruments that seek to regulate or govern the modification of human germline or somatic cells. So far, in international law there is no binding legal instrument dedicated to human genome modification. All there is are a few soft-law instruments, of which the 1997 UNESCO Universal Declaration on Human Genome and Human Rights is the most important. These instruments will be analyzed in this chapter. However, as one zooms out to the larger field of bioethics law, some binding legal instruments with regional scope become relevant. These include the Council of Europe's Convention for the Protection of Human Rights and Dignity of the Human Being with regard to the Application of Biology and Medicine (Oviedo Convention) and some EU directives and regulations. These instruments are discussed in detail in a separate chapter on the 'European' regulatory regime. ${ }^{24}$

The third challenge is the nature of the actors. The international governance of human genome modification, whether that be germline or somatic, is not just the province of states and intergovernmental organizations, but it is also one where dozens of non-governmental actors, generally called 'civil society', participate. Between 2015 and early 2018, at least 61 ethics reports and statements have been crafted by more than 50 countries and civil society organizations across the globe, many of them academic, including the American and European Societies of Human Genetics, the European Society of Human Reproduction and Embryology, and the International Society for Stem Cell Research, the Nuffield Council in the United Kingdom, the Danish Council on Ethics, industry groups and organizations including the Biotechnology Innovation Organization and various genome-editing biotech companies, and political groups such as the '2015 White House'. However, for the legal scholar who aspires to describe this growing field, this richness and diversity of participants complicates the task of assessing the legal value of the declarations they issue. ${ }^{25}$ It is beyond the scope of this book to discuss them all, but we will point out a few

\footnotetext{
November 2018. On international bioethics law, see, in general: R Andorno, 'Towards an International Bioethics Law' (2004) 2-3 Journal International de Bioéthique 131, 131-49.

${ }^{24}$ See, in this book, Part 2, Section II, Chapter 6. We recommend readers who want to explore more in depth broader international bioethical standards to read further. For a bibliography, see, F Molnár-Gábor, 'Bioethics' (Max Planck Encyclopedia of Public International Law, last updated January 2015).

${ }^{25}$ For a survey of 'ethical statements' on the matter, see, in general, C Brokowski, 'Do CRISPR Germline Ethics Statements Cut It?' (2018) 1:2 The CRISPR Journal 115, 115-125. On Brokowski's survey, see, in this chapter, Section II.4.
} 
Pre-editing version of the corresponding chapter in Andrea Boggio, Cesare P.R. Romano, Jessica Almqvist (eds.), Human Germline Genome Modification and the Right to Science: A Comparative Study of National Laws and Policies, Cambridge University Press, 2019 (ISBN: 9781108499873)

that, in our opinion, might become the basis for government-sanctioned international legal standards in the future.

Besides the Council of Europe and the European Union, so far, the international organizations that have been most active on the question of human genome modification are, at the global level, the United Nations, through some of its specialized agencies, mainly the United Nations Educational, Scientific and Cultural Organization (UNESCO) and the World Health Organization (WHO), and UN bodies, such as the General Assembly and the Human Rights Council, and, at the regional level, the Organisation for Economic Co-operation and Development (OECD). In the subsections below we will analyze what has been done in each of these fora to address and respond to the opportunities and challenges presented by the possibility to modify the human genome in general, and germline cells in specific.

\section{1) UNESCO}

The United Nations Educational, Scientific and Cultural Organization (UNESCO) is a 'specialized agency' of the United Nations. ${ }^{26}$ Presently, it counts 195 members, although the United States and Israel announced their withdrawal on 1 January 2019 due to the admission of Palestine to the organization in $2011 .{ }^{27}$ Of all UN specialized agencies it is probably the one with

\footnotetext{
26 "Specialized Agencies are legally independent international organizations with their own rules, membership, organs and financial resources [that] were brought into relationship with the United Nations through negotiated agreements. Some of the agencies existed before the First World War, some were associated with the League of Nations, others were created almost simultaneously with the United Nations and yet others were created by the United Nations itself to meet emerging needs. Given the diversity of their respective fields of action, history and experience, each agency has its own needs and concerns, not to speak of corporate culture". Chief Executives Board for Coordination, 'Directory of United Nations System Organizations' (Chief Executives Board Secretariat, 2016) $<$ www.unsystem.org/members/specialized-agencies> accessed 8 November 2018.

${ }^{27}$ See United States Withdraws from UNESCO, U.S. Department of State, Press Release, 12 October 2017. The decision takes effect on 31 December 2018. US Department of State, 'The United States Withdraws From UNESCO' (2017) <www.state.gov/r/pa/prs/ps/2017/10/274748.htm> accessed on 28 December 2018. This is not the first time the U.S. turns its back to UNESCO. During the 1970s and 1980s, UNESCO was denounced by the United States and some of its allies as a platform for communists and Third World dictators to attack the West. In 1984, the United States withheld its contributions and withdrew from the organization in protest, followed by the United Kingdom and Singapore in 1985. The UK rejoined in 1997. The United States rejoined in 2003, followed by Singapore in 2007. For the Israeli withdrawal, see Declaration by UNESCO Director-General Audrey Azoulay on the withdrawal of Israel from the Organization, UNESCO, 29 December 2017. UNESCO, 'Declaration by UNESCO Director-General Audrey Azoulay on the withdrawal of Israel from the Organization' (2017)
} 
Pre-editing version of the corresponding chapter in Andrea Boggio, Cesare P.R. Romano, Jessica Almqvist (eds.), Human Germline Genome Modification and the Right to Science: A Comparative Study of National Laws and Policies, Cambridge University Press, 2019 (ISBN: 9781108499873)

the broadest mandate, which, in its history, has been both a blessing and a curse. Its stated purpose is "to contribute to peace and security by promoting collaboration among the nations through education, science and culture in order to further universal respect for justice, for the rule of law and for the human rights and fundamental freedoms". ${ }^{28}$ It pursues these objectives through five major programs: education, natural sciences, social/human sciences, culture and communication/information.

Probably, UNESCO's most famous activity is the attempt to protect the world's cultural and natural heritage through its World Heritage sites list. However, it is less known that over the past twenty years, it has been active on the question of the human genome and bioethics, too. In 1993, the Secretary-General of UNESCO established the International Bioethics Committee (IBC) to "follow progress in the life sciences and its applications in order to ensure respect for human dignity and freedom". ${ }^{29}$ The IBC is currently composed of 36 persons, mostly specialists in medicine and biology but counting also several legal scholars, and reflecting, as all UN bodies, the whole organization membership according to the principle of 'equitable geographic representation'. ${ }^{30}$ Over the years it has adopted three soft law instruments in the field of biotechnology that are crucial for the purposes of this volume.

\section{a) UNESCO Universal Declaration on Human Genome and Human Rights (1997)}

On 11 November 1997, the members of UNESCO adopted, unanimously but after much deliberation and discussion at the IBC, the Universal Declaration on Human Genome and Human Rights. $^{31}$ This declaration forms "the basis of 'soft law' in the area of human genome

\footnotetext{
$<$ https://en.unesco.org/news/declaration-unesco-director-general-audrey-azoulay-withdrawal-israel-organization> accessed on 28 December 2018.

${ }^{28}$ Constitution of UNESCO, 4 UNTS 275, art 1.

${ }^{29}$ See UNESCO, 'International Bioethics Committee (IBC)' (2017) <www.unesco.org/new/en/social-and-humansciences/themes/bioethics/international-bioethics-committee/> accessed 8 November 2018. On the IBC and its role in the governance of bioethics, see, in general: A Bagheri, J Moreno, and S Semplici (eds), Global Bioethics: The Impact of the UNESCO International Bioethics Committee (Springer 2016).

${ }^{30}$ See UNESCO, 'Members of the International Bioethics Committee' (2019) <www.unesco.org/new/en/social-andhuman-sciences/themes/bioethics/international-bioethics-committee/members/> accessed 8 November 2018.

${ }^{31}$ UNESCO, Universal Declaration on the Human Genome and Human Rights (adopted at the 29th Session of the General Conference on 11 November 1997) BR/2001/PI/H/1. The 1997 Declaration was subsequently endorsed by the United Nations General Assembly with Resolution AIRES/53/152 on 9 December 1998 at its 53rd session.
} 
governance". ${ }^{32}$ The main objective of this declaration is to preserve the human genome from improper manipulations that may imperil the identity and physical integrity of future generations. ${ }^{33}$ The first four articles sets out the broadest principles of bioethics relating to human genome. The first one is contained in Article 1: "The human genome underlies the fundamental unity of all members of the human family, as well as the recognition of their inherent dignity and diversity. In a symbolic sense, it is the heritage of humanity". The second regards 'dignity', an overarching but ill-defined concept in international bioethics law: “(a) Everyone has a right to respect for their dignity and for their rights regardless of their genetic characteristics; (b) That dignity makes it imperative not to reduce individuals to their genetic characteristics and to respect their uniqueness and diversity". ${ }^{34}$ The third one is the mutability and individuality of the human genome: "[t]he human genome, which by its nature evolves, is subject to mutations. It contains potentialities that are expressed differently according to each individual's natural and social environment, including the individual's state of health, living conditions, nutrition and education". ${ }^{35}$ Finally, Article 4 proclaims: "The human genome in its natural state shall not give rise to financial gains".

Of the four, the most controversial statement is probably that the human genome is the "heritage of humanity". The 'common heritage of mankind' (also referred to gender-neutrally as 'common heritage of humanity', or 'common heritage of humankind') is a philosophical concept, an international legal principle and, in the context of the human genome, a biological concept, too. ${ }^{36}$ Philosophically, its roots can be traced back to the father of international law, Hugo Grotius, and to the father of philosophical Enlightenment, Immanuel Kant. However, the concept started acquiring normative significance beginning the late 1950s, as humanity developed technology to reach and exploit the resources in spaces that had been hitherto unreachable (i.e., Antarctica, the sea bed of the high sea and outer space). ${ }^{37}$ The need to avoid a scramble for those resources in a world locked in a nuclear-armed Cold War and the process of decolonization, which created scores

\footnotetext{
${ }^{32}$ C Kuppuswamy, The International Legal Governance of the Human Genome (Routledge 2009) 28.

${ }^{33} \mathrm{R}$ Andorno, Principles of International Biolaw: Seeking Common Ground at the Intersection of Bioethics and Human Rights (Brussels, Bruylant 2013) 14.

${ }^{34}$ UNESCO 1997 Declaration on the Human Genome (n 31), art 2.

35 ibid, art 3.

${ }^{36}$ Kuppuswamy (n 32) 49.

${ }^{37}$ On the notion of 'common heritage of mankind' in international law, see, in general, R Wolfrum, 'Common Heritage of Mankind' (Max Planck Encyclopedia of Public International Law, last updated November 2009).
} 
Pre-editing version of the corresponding chapter in Andrea Boggio, Cesare P.R. Romano, Jessica Almqvist (eds.), Human Germline Genome Modification and the Right to Science: A Comparative Study of National Laws and Policies, Cambridge University Press, 2019 (ISBN: 9781108499873)

of developing countries eager to acquire a share of the resources yet to be reached, helped turn the old philosophical concept into a legal principle. The principle eventually found its way in a number of major multilateral treaties governing the so-called 'global commons', including the high seas, with the 1982 United Nations Convention on the Law of the Sea, ${ }^{38}$ and the moon and other celestial bodies. ${ }^{39}$

The principle is said to have multiple dimensions: non-appropriation; international management; benefit sharing; peaceful use and preservation for the benefit of future generations. ${ }^{40}$ Non-appropriation holds that common heritage of mankind is res communis, common property of mankind. As such, it cannot be appropriated by anyone, state or individuals. Instead, common heritage must be managed and exploited jointly, though international agencies that can ensure the benefits are equally and proportionally shared by all states. Finally, shared spaces and resources cannot be used for non-peaceful uses and must be managed in such a way as to be able to pass them to the next generation as they have been received from the previous.

When UNESCO issued its 1997 Declaration, boldly declaring that "the human genome [is], [i]n a symbolic sense, .... the heritage of humanity", it made heads turn. Albeit the concept of common heritage of mankind has been invoked in recent decades for much more than just global commons, such as the internet, cultural heritage, photosynthesis, the Earth's climate, and many others, pushing its practical and logical limits, its application to the human genome is far from obvious. Save for a few scholars who have read into that statement more than it says, ${ }^{41}$ it does not seem possible to conclude that human genome is actually a common property of all humanity, not even according to the Declaration itself. The reasons are several. First, the Declaration does not rule out appropriation. Although Article 4 declares that "[ $[\mathrm{t}] \mathrm{he}$ human genome in its natural state shall not give rise to financial gains", Article 3 recognizes that it is at the same time common to everyone and individual to each: "[t]he human genome ... contains potentialities that are expressed

\footnotetext{
${ }^{38}$ Convention on the Law of the Sea, (published 10 December 1982, entered into force 16 November 1994) 1833 UNTS 397.

${ }^{39}$ Treaty on Principles Governing the Activities of States in the Exploration and Use of Outer Space, including the Moon and Other Celestial Bodies (signed 27 January 1967, entered into force 10 October 1967) 18 UST 2410.

${ }^{40} \mathrm{~K}$ Baslar, The Concept of Common Heritage of Mankind in International Law (Nijhoff 1998) 82.

${ }^{41}$ eg Kuppuswamy (n 32).
} 
differently according to each individual's natural and social environment, including the individual's state of health, living conditions, nutrition and education". Second, there is not yet an international regime in place to manage the human genome and ensure benefit sharing. All the declaration does is to call for solidarity and international cooperation in human genetic research, ${ }^{42}$ and to ask the IBC to "contribute to the dissemination of the principles set out in this Declaration and to the further examination of issues raised by their applications and by the evolution of the technologies in question". ${ }^{43}$ Granted, a mere declaration could not create an international regime to manage a common resource, but the fact that a binding legal instrument on the status of the human genome has not been adopted is indicative of states' opinio juris.

In any event, the Declaration clearly stops short of declaring human genome as common heritage, with all legal consequences that it entails. It intentionally qualifies the statement by saying "in a symbolic sense". ${ }^{44}$ Moreover, unless the human genome is considered to be an exception to the other international regimes created so far for the other global commons, it is clear that the status of 'common heritage' entails the creation of mechanisms for management and benefits sharing. That cannot be reconciled with the idea that the human genome is sacred and unmodifiable.

Articles 5 to 8 reassert well established rights that individuals subjects enjoy when participating in biomedical research. They include the right to informed consent, ${ }^{45}$ the prohibition of discrimination, ${ }^{46}$ confidentiality of genetic data, ${ }^{47}$ and the right to "just reparation for any damage sustained as a direct and determining result of an intervention affecting his or her genome". ${ }^{48}$ These articles are followed by a claw back clause, which provides that "to protect human rights and fundamental freedoms, limitations to the principles of consent and

${ }^{42}$ UNESCO Declaration on the Human Genome (n 31) art 17-19.

43 ibid, art 24.

${ }^{44}$ ibid, art 1.

45 ibid, art 5.

46 ibid, art 6.

47 ibid, art 7.

48 ibid, art 8. 
confidentiality may only be prescribed by law, for compelling reasons within the bounds of public international law and the international law of human rights". ${ }^{49}$

Articles 10 to 12.a set three limits for genetic research: "No research or research applications concerning the human genome...should prevail over respect for the human rights, fundamental freedoms and human dignity of individuals or, where applicable, of groups of people"; 50 "practices which are contrary to human dignity, such as reproductive cloning of human beings, shall not be permitted", ${ }^{51}$ and "benefits from advances in biology, genetics and medicine, concerning the human genome, shall be made available to all, with due regard for the dignity and human rights of each individual". ${ }^{52}$ Moreover, "States should respect and promote the practice of solidarity towards individuals, families and population groups who are particularly vulnerable to or affected by disease or disability of a genetic character. They should foster, inter alia, research on the identification, prevention and treatment of genetically based and genetically influenced diseases, in particular rare as well as endemic diseases which affect large numbers of the world's population." 53

Article $12 . b$ to 16 set out the conditions for the conduct of research. First, "[f]reedom of research, which is necessary for the progress of knowledge, is part of freedom of thought. The applications of research, including applications in biology, genetics and medicine, concerning the human genome, shall seek to offer relief from suffering and improve the health of individuals and humankind as a whole". ${ }^{54}$ Second, "[t]he responsibilities inherent in the activities of researchers, including meticulousness, caution, intellectual honesty and integrity in carrying out their research as well as in the presentation and utilization of their findings, should be the subject of particular attention in the framework of research on the human genome, because of its ethical and social implications. Public and private science policy-makers also have particular responsibilities in this

\footnotetext{
49 ibid, art 9.

50 ibid, art 10.

51 ibid, art 11.

52 ibid, art 12.a.

53 ibid, art 17.

54 ibid, art 12.b.
} 
respect" ${ }^{55}$ Third, "States should take appropriate measures to foster the intellectual and material conditions favourable to freedom in the conduct of research on the human genome and to consider the ethical, legal, social and economic implications of such research...". ${ }^{56}$ Fourth, "States should take appropriate steps to provide the framework for the free exercise of research on the human genome ... to safeguard respect for human rights, fundamental freedoms and human dignity and to protect public health. They should seek to ensure that research results are not used for nonpeaceful purposes". ${ }^{57}$ And, finally, "States should recognize the value of promoting ... the establishment of independent, multidisciplinary and pluralist ethics committees to assess the ethical, legal and social issues raised by research on the human genome and its applications". ${ }^{58}$

States have several duties with regard to fostering international cooperation in genetic research. They should "... make every effort ... to continue fostering the international dissemination of scientific knowledge concerning the human genome, human diversity and genetic research and, in that regard, to foster scientific and cultural co-operation, particularly between industrialized and developing countries." 59 Article 19 continues: "a) In the framework of international co-operation with developing countries, states should seek to encourage measures enabling: (i) assessment of the risks and benefits pertaining to research on the human genome to be carried out and abuse to be prevented; (ii) the capacity of developing countries to carry out research on human biology and genetics, taking into consideration their specific problems, to be developed and strengthened; (iii) developing countries to benefit from the achievements of scientific and technological research so that their use in favor of economic and social progress can be to the benefit of all; (iv) the free exchange of scientific knowledge and information in the areas of biology, genetics and medicine to be promoted....".

Finally, and crucially for the purposes of this book, according to Article 24, the International Bioethics Committee of UNESCO should make recommendations and give advice

\footnotetext{
55 ibid, art 13.

56 ibid, art 14.

$57 \mathrm{ibid}$, art 15.

58 ibid, art 16.

59 ibid, art 18.
} 
Pre-editing version of the corresponding chapter in Andrea Boggio, Cesare P.R. Romano, Jessica Almqvist (eds.), Human Germline Genome Modification and the Right to Science: A Comparative Study of National Laws and Policies, Cambridge University Press, 2019 (ISBN: 9781108499873)

concerning the follow-up of this declaration, including regarding "the identification of practices that could be contrary to human dignity, such as germ-line interventions". ${ }^{60}$

\section{b) UNESCO International Declaration on Human Genetic Data (2003)}

In the early 2000s, the Human Genome Project breakthrough and the growing number of national genetic banking projects were the spur for the adoption of the UNESCO International Declaration on Human Genetic Data. This instrument is a fascinating example of the interplay between scientific advancements and the development of a legal framework to regulate them. On 15 February 2001, the Human Genome Project announced it had completed sequencing 90 percent of all three billion base pairs in the human genome. ${ }^{61}$ UNESCO had been following these developments. The IBC had already considered the issues created by the collection of human genetic data and had produced a report entitled "Confidentiality and Genetic Data" in June 2000. In May 2001, the Director-General of UNESCO announced he had asked the IBC to examine the possibility of drafting an international instrument on human genetic data. In May 2002, the IBC issues a second report, entitled "Human Genetic Data: Preliminary Study of the IBC on their Collection, Processing, Storage and Use". ${ }^{62}$ On 14 April 2003, the National Human Genome Research Institute, the U.S. Department of Energy and their partners in the International Human Genome Sequencing Consortium announced the successful completion of the Human Genome Project. On 16 October 2003, UNESCO member states adopted unanimously the International Declaration on Human Genetic Data. ${ }^{63}$

Article 1 sets the goal of the Declaration as "...to ensure the respect of human dignity and protection of human rights and fundamental freedoms in the collection, processing, use and storage of human genetic data, human proteomic data and of the biological samples from which they are derived ... in keeping with the requirements of equality, justice and solidarity, while giving due

\footnotetext{
${ }^{60} \mathrm{ibid}$, art 24 (italics added).

${ }^{61}$ International Human Genome Sequencing Consortium, Initial Sequencing and Analysis of the Human Genome, (2001) 409 Nature 860, 860-921.

${ }^{62}$ UNESCO, International Bioethics Committee, Human Genetic Data: Preliminary Study by the IBC on its Collection, Processing, Storage and Use (SHS-503/01/CIB-8/3 (Rev.2), 15 May 2002).

${ }^{63}$ UNESCO, International Declaration on Human Genetic Data (adopted at the 32nd Session of the General Conference on 16 October 2003).
} 
consideration to freedom of thought and expression, including freedom of research; to set out the principles which should guide States in the formulation of their legislation and their policies on these issues; and to form the basis for guidelines of good practices in these areas for the institutions and individuals concerned." ${ }^{64}$ The Declaration defines 'human genetic data' as "information about heritable characteristics of individuals obtained by analysis of nucleic acids or by other scientific analysis", ${ }^{65}$ and 'human proteomic data' as "information pertaining to an individual's proteins including their expression, modification and interaction". ${ }^{66}$

Recognizing that, "[e]ach individual has a characteristic genetic makeup", and that, "[n]evertheless, a person's identity should not be reduced to genetic characteristics, since it involves complex educational, environmental and personal factors and emotional, social, spiritual and cultural bonds with others and implies a dimension of freedom", ${ }^{67}$ the Declaration calls for collecting, treating, using, and storing genetic data using transparent and ethically acceptable procedures. ${ }^{68}$ As a general principle, "[a]ny collection, processing, use and storage of human genetic data, human proteomic data and biological samples shall be consistent with the international law of human rights." ${ }^{69}$ Under Article 5, 'human genetic data' and 'human proteomic data' may be “...collected, processed, used and stored only for the purposes of: (i) diagnosis and health care, including screening and predictive testing; (ii) medical and other scientific research, including epidemiological, especially population-based genetic studies, as well as anthropological or archaeological studies...; (iii) forensic medicine and civil, criminal and other legal proceedings, ...; (iv) or any other purpose consistent with the Universal Declaration on the Human Genome and Human Rights and the international law of human rights".

At the data collection stage, the Declaration emphasizes "prior, free, informed and express consent, without inducement by financial or other personal gain" of the person providing the

\footnotetext{
64 ibid, art 1.a.

65 ibid, art 2.i.

66 ibid, art 2.ii.

67 ibid, art3.

68 ibid art 6.

69 ibid, art 1.b.
} 
data. ${ }^{70}$ Data collected for one purpose should not be used for a different purpose that is incompatible with the original consent. ${ }^{71}$ At the processing stage, the Declaration recommends that genetic data linked to an identifiable person not be disclosed nor made accessible to third parties - in particular, employers, insurance companies, educational institutions, or families except for "an important public interest reason in cases restrictively provided for by domestic law that is consistent with the international law of human rights." 72 Moreover, "[t $t$ he provisions of this Declaration apply ... except in the investigation, detection and prosecution of criminal offences and in parentage testing that are subject to domestic law that is consistent with the international law of human rights." 73

Finally, states "should regulate .... the cross-border flow of human genetic data, human proteomic data and biological samples so as to foster international medical and scientific cooperation and ensure fair access to these data" ${ }^{74}$ Also, "[s]tates should make every effort ... to continue fostering the international dissemination of scientific knowledge concerning human genetic data and human proteomic data and, in that regard, to foster scientific and cultural cooperation, particularly between industrialized and developing countries". ${ }^{75}$ Scientists are encouraged to "endeavor to establish cooperative relationships, based on mutual respect with regard to scientific and ethical matters and ... should encourage the free circulation of human genetic data and human proteomic data in order to foster the sharing of scientific knowledge .... To this end, they should also endeavor to publish in due course the results of their research. ${ }^{76}$ "Benefits resulting from the use of human genetic data, human proteomic data or biological samples collected for medical and scientific research should be shared with the society as a whole and the international community". ${ }^{77}$

\footnotetext{
70 ibid, art 8.

71 ibid, art 16.

72 ibid, art 16.a.

73 ibid, art 1.c.

74 ibid, art 18.a.

75 ibid, art 18.b.

76 ibid, art 18.c.

77 ibid, art 19.a.
} 
Pre-editing version of the corresponding chapter in Andrea Boggio, Cesare P.R. Romano, Jessica Almqvist (eds.), Human Germline Genome Modification and the Right to Science: A Comparative Study of National Laws and Policies, Cambridge University Press, 2019 (ISBN: 9781108499873)

c) UNESCO Universal Declaration on Bioethics and Human Rights (2005)

The third relevant UNESCO 'soft law' instrument is the Universal Declaration on Bioethics and Human Rights. ${ }^{78}$ It was adopted by acclamation by UNESCO member states on 10 January 2005. This was the end of a process that began with an invitation by the 2001 General Conference to the UNESCO International Bioethics Committee to report on the possibility of elaborating a universal instrument on bioethics. ${ }^{79}$ Of the triad, the 2005 Declaration is the broadest in scope. It "addresses ethical issues related to medicine, life sciences and associated technologies as applied to human beings, taking into account their social, legal and environmental dimensions". ${ }^{80}$ In the words of UNESCO, "its originality lies in the fact that it goes much further than the various professional codes of ethics concerned. It entails reflection on societal changes and even on global balances brought about by scientific and technological developments. To the already difficult question posed by life sciences - how far can we go? - other queries must be added concerning the relationship between ethics, science and freedom". ${ }^{81}$ Notably, although the Declaration is addressed to states, "[a]s appropriate and relevant, it also provides guidance to decisions or practices of individuals, groups, communities, institutions and corporations, public and private". 82

For the first time in the history of bioethics, the international community compiled a list of fundamental principles of bioethics within a single text and expressed its desire to respect and apply them. ${ }^{83}$ These include respect for "human dignity, human rights and fundamental freedoms"; ${ }^{84}$ giving priority to the "interests and welfare of the individual ... over the sole interest

\footnotetext{
${ }^{78}$ UNESCO, Universal Declaration on Bioethics and Human Rights (adopted by the General Conference on 19 October 2005).

${ }^{79}$ J F Martin, 'The National Bioethics Committees and the Universal Declaration on Bioethics and Human Rights: Their Potential and Optimal Functioning' in A Bagheri, J Moreno, and S Semplici (eds), Global Bioethics: The Impact of the UNESCO International Bioethics Committee (Springer 2016) 125-136.

${ }^{80}$ Universal Declaration on Bioethics and Human Rights (n 78), art 1.1.

81 ibid.

82 ibid, art 1.2 .

${ }^{83}$ On the importance of the Universal Declaration on Bioethics and Human Rights, see, in general, R Andorno, 'Global Bioethics at UNESCO: in Defense of the Universal Declaration on Bioethics and Human Rights' in M Grodin and others (eds), Health and Human Rights in a Changing World (Routledge 2013) 77-85.

${ }^{84}$ Universal Declaration on Bioethics and Human Rights (n 78), art 3.1.
} 
of science or society"; ${ }^{85}$ maximization of benefits and minimization of harm deriving from research; ${ }^{86}$ autonomy of individuals to make decisions and responsibility for those decisions; ${ }^{87}$ prior, free and informed consent of those subject to research ${ }^{88}$ respect for human vulnerability and personal integrity; ${ }^{89}$ respect for privacy and confidentiality; ${ }^{90}$ respect for the fundamental equality of all human beings in dignity and rights $;{ }^{91}$ prohibition of discrimination and stigmatization; ${ }^{92}$ respect for cultural diversity and pluralism; ${ }^{93}$ solidarity among human beings and international cooperation; $;{ }^{94}$ sharing of benefits; $;{ }^{95}$ promotion of health and social development; $;{ }^{96}$ protection of future generations, ${ }^{97}$ and of the environment, the biosphere and biodiversity. ${ }^{98}$

To fulfil these principles, the Declaration calls on states to promote "[p]rofessionalism, honesty, integrity and transparency in decision-making ... [and] ... to use the best available scientific knowledge and methodology in addressing and periodically reviewing bioethical issues", ${ }^{99}$ dialogue between "persons and professionals concerned and society as a whole", ${ }^{100}$ and "[o]pportunities for informed pluralistic public debate, seeking the expression of all relevant opinions, should be promoted". ${ }^{101}$ States are also urged to create ethics committees to assess the relevant ethical, legal, scientific and social issues related to research projects involving human beings, provide advice on ethical problems in clinical settings, and assess scientific and technological developments; ${ }^{102}$ to promote "appropriate assessment and adequate management of

\footnotetext{
85 ibid, art 3.2.

86 ibid, art 4.

87 ibid art 5.

88 ibid, art 6.

89 ibid, art 8.

90 ibid, art 9.

91 ibid, art 10.

92 ibid, art 11.

93 ibid, art 12.

94 ibid, art 13.

95 ibid, art 15.

96 ibid, art 14.

97 ibid, art 16.

98 ibid, art 17.

${ }^{99}$ ibid, art 18.1.

100 ibid, art 18.2.

101 ibid, art 18.3.

102 ibid, art 19.
} 
Pre-editing version of the corresponding chapter in Andrea Boggio, Cesare P.R. Romano, Jessica Almqvist (eds.), Human Germline Genome Modification and the Right to Science: A Comparative Study of National Laws and Policies, Cambridge University Press, 2019 (ISBN: 9781108499873)

risk related to medicine, life sciences and associated technologies"; ${ }^{103}$ to facilitate "transnational practices"; ${ }^{104}$ and to foster "international dissemination of scientific information and encourage the free flow and sharing of scientific and technological knowledge". ${ }^{105}$

\section{d) Overall assessment of the work of UNESCO and future developments}

With its three declarations, UNESCO attempted to provide a general framework with global reach, which sets out the fundamental principles and rights that must be respected in the process of regulating scientific advancements, in the field of biomedicine. While the effort should be appreciated, in the end these instruments, being not binding, fail to provide the regulatory framework that the policy impetus intended to have. By and large, they simply echo already wellestablished international instruments on bioethics, such as the World Medical Association's Declaration of Helsinki, which was adopted back in 1964 and has been updated several times since, ${ }^{106}$ and the 2002 Ethical Guidelines for Biomedical Research Involving Human Subjects of the Council for International Organizations of Medical Sciences, ${ }^{107}$ and the best practices already followed by most developed states of the world.

However, breaking new ground and originality is hardly the point of international lawmaking efforts. In a community made of sovereign states, progress can be achieved only gradually, by broadening support of these efforts to as many states as possible. It means most international instruments, and certainly those of a global scope, are just the minimum-common-denominator that is conceivably achievable between almost 200 sovereign states. Often, universal declarations are scorned for the non-binding nature and vague language, but that is inevitable given the nature of the international community. These legal instruments are intentionally non-binding for a reason. Norm-making through 'soft law' instruments as opposed through 'hard law' ones, such as treaties, which create binding legal obligations, permits states to take on commitments they otherwise

\footnotetext{
103 ibid, art 20.

104 ibid, art 21.

105 ibid, art 24.1.

${ }^{106}$ World Medical Association, Declaration of Helsinki: Recommendations Guiding Physicians in Biomedical Research Involving Subjects (as amended through 2013).

${ }^{107}$ Council for International Organizations of Medical Sciences, International Ethical Guidelines for Biomedical Research Involving Human Subjects (CIOMS, Geneva, 2002).
} 
Pre-editing version of the corresponding chapter in Andrea Boggio, Cesare P.R. Romano, Jessica Almqvist (eds.), Human Germline Genome Modification and the Right to Science: A Comparative Study of National Laws and Policies, Cambridge University Press, 2019 (ISBN: 9781108499873)

would not have taken. Furthermore, soft law instruments present the advantage of permitting countries to gradually become familiar with the proposed standards before they are confronted with the adoption of enforceable rules or with the development of a binding instrument. As we saw, soft law instruments can, and often do, morph into hard law over time, in the form of customary law, as long as they are followed. ${ }^{108}$

As we will see throughout this volume, vague or lacking definitions is not just a problem of international bioethics instruments. National laws, and, disturbingly, even criminal norms, can often be as vague and undetermined. Again, it is not the result of oversight but rather a deliberate choice. Except for very technical terms, lawmakers typically prefer not to define precisely most of the words they use. Rather, they tend to leave that task to common understanding and, ultimately, to courts' interpretation. Flexibility, especially in a field fast developing like bio-medical science, is a virtue. In the specific case of UNESCO, vagueness is unavoidable because it is impossible to reach a global agreement on the precise meaning of terms such as "dignity", "autonomy", "justice", "benefit", "harm" or "solidarity", terms that have a long philosophical history and are, to some extent, conditioned by cultural factors. Universal principles must be contextualized before they can be applied in a meaningful sense at the national level, but contextualization without a global framework of reference opens the door to diverging standards and goes against the very fundamental idea undergirding all international law: the belief that humanity is one, even if it is divided in several sovereign states.

As we saw, the more recent UNESCO declaration directly relevant to the topic book was issued in 2005. At the speed at which genetic engineering develops, it is a century ago. Since then, it has fallen to the IBC to continue monitoring development and to issue reflections on what states and UNESCO ought to do. In October 2015, the IBC issued a report entitled "Updating Its Reflection on the Human Genome and Human Rights", ${ }^{109}$ taking into account its previous

\footnotetext{
108 See, in this chapter, Section I.2.

${ }^{109}$ UNESCO, International Bioethics Committee: Updating Its Reflection on the Human Genome and Human Rights (SHS/YES/IBC-22/15/2 REV.2, 2 October 2015).
} 
recommendations on the matter ${ }^{110}$ and the three UNESCO declarations. In this report, the IBC called upon states to agree on a moratorium on genome engineering of the human germline, at least as long as the safety and efficacy of the procedures are not adequately proven as treatments, and to produce an international legally binding instrument to ban human cloning for reproductive purposes; ${ }^{111}$ to renounce the possibility of acting alone in relation to engineering the human genome and accept to cooperate on establishing a shared, global standard for this purpose, building on the principles set out in the Universal Declaration on the Human Genome and Human Rights and the Universal Declaration on Bioethics and Human Rights; ${ }^{112}$ and to encourage the adoption of rules, procedures and solutions, which can be as non-controversial as possible, especially with regard to the issues of modifying the human genome and producing and destroying human embryos. ${ }^{113}$

The IBC also underlined the need to adopt legislative and other measures to ensure that quality-assured information be provided with regard to direct-to-consumer tests, including nonmedical tests, in order to mitigate risks and avoid misuse; ${ }^{114}$ to organize health care systems so that the new opportunities offered by precision/personalized medicine can be shared with society as a whole, without becoming a new source of inequality and discrimination; ${ }^{115}$ to develop a trustworthy form of governance for biobanks and biobank secrecy and harmonize the corresponding rules at the international level; ${ }^{116}$ and to ensure that new possibilities of genetic screening and in particular non-invasive prenatal testing comply both with the right to autonomous choices and the principles of non-discrimination and non-stigmatization and respect for every human being in her or his uniqueness. ${ }^{117}$ Finally, the IBC called on states and UNESCO to consider

\footnotetext{
${ }^{110}$ For a list of International Bioethics Committee's advices and recommendations, see UNESCO, 'Reports and Advices of the International Bioethics Committee' (2017) <www.unesco.org/new/en/social-and-humansciences/themes/bioethics/international-bioethics-committee/reports-and-advices/> accessed 8 November 2018.

${ }^{111}$ UNESCO, International Bioethics Committee, Updating Its Reflections (n 109), para. 118.

112 ibid, para 116.

113 ibid, para 113.

114 ibid, para 120-121.

115 ibid, para 122.

116 ibid, para 123.

117 ibid, para 125.
} 
Pre-editing version of the corresponding chapter in Andrea Boggio, Cesare P.R. Romano, Jessica Almqvist (eds.), Human Germline Genome Modification and the Right to Science: A Comparative Study of National Laws and Policies, Cambridge University Press, 2019 (ISBN: 9781108499873)

revising the three declarations, emphasizing that the cogency of principles remains untouched, but some applications could need updating. ${ }^{118}$

The IBC concluded with a plea: "We are human because of the interplay of many biological, historical, cultural determinants, which preserve the feeling of our fundamental unity and nourish the richness of our diversity. The international community, States and governments, scientists, actors of civil society and individuals are called upon to consider the human genome as one of the premises of freedom itself and not simply as raw material to manipulate at leisure. At the same time, considering that scientific advancements in this field are likely to offer unprecedented tools against diseases, it is crucial to acknowledge that these opportunities should never become the privilege of few. What is heritage of humanity entails sharing both of responsibilities and benefits". 119

\section{2) The World Health Organization (WHO)}

The World Health Organization (WHO) is another specialized agency of the United Nations whose mission is "the attainment by all peoples of the highest possible level of health". ${ }^{120}$ This goal is pursued through three 'core functions': (1) 'normative' (i.e. drafting and adopting treaties, regulations and other non-binding legal standards and recommendations); (2) 'directing and coordinating', including launching focused programs, such as those on "poverty and health, essential medicine and specific diseases; and (3) 'research and technical cooperation', including disease eradication and coordinating response to health emergencies. ${ }^{121}$

The WHO is mostly known for its work on the latter two functions. Compared to many other UN agencies, the WHO has been a relatively less active law-maker. ${ }^{122}$ Historically, it has chosen to eschew the legal approach in favor of developing international guidelines of practice for

\footnotetext{
118 ibid, para 127.

119 ibid, para 128.

${ }^{120}$ WHO Constitution, 14 UNTS 185, art 1.

$121 \mathrm{ibid}$, art 2. See, in general, G L Burci and C-H Vignes, The World Health Organization (Kluwer 2004).

122 See, in general, L Gostin and D Sridhar, 'Global Health and the Law' (2014) 370 New England Journal of Medicine 1732, 1732-1740.
} 
Pre-editing version of the corresponding chapter in Andrea Boggio, Cesare P.R. Romano, Jessica Almqvist (eds.), Human Germline Genome Modification and the Right to Science: A Comparative Study of National Laws and Policies, Cambridge University Press, 2019 (ISBN: 9781108499873)

specific health issues. ${ }^{123}$ So far, only three international legal instruments have been adopted under its aegis: the Framework Convention on Tobacco Control, ${ }^{124}$ the International Health Regulations, ${ }^{125}$ and the Pandemic Influenza Preparedness Framework. ${ }^{126}$

The WHO's reluctance to engage in norm-setting and to make genetics and genomics a priority, preferring instead to focus on minimizing public health risks and expanding health care coverage, ${ }^{127}$ explains why there are no WHO standards applicable to genetic research, in general, and human genome modification in particular. The WHO's contribution to the governance of genomic research has been mostly through 'directing and coordinating' and encouraging 'research and technical cooperation'. For instance, the WHO's Human Genomics in Global Health Initiative aims to provide information and raise awareness within the health sector, governments and the wider public on the health challenges and opportunities of human genomics, and to share information and to develop innovative approaches in the field of human genetics and genomics. ${ }^{128}$ It builds on the work of the former Human Genetics Programme and of the Initiative on Genomics $\&$ Public Health, acting under the responsibility of the Department of Service Delivery and Safety and working across the Organization, with WHO Collaborating Centers, NGOs and other international organizations active in this field. ${ }^{129}$

Until recently, the WHO had left the driver's seat on the question of the governance of human genome manipulation to UNESCO, leading some observers to accuse UNESCO of having exceeded its mandate and trespassed on WHO turf. ${ }^{130}$ However, it is hard to see how the charge

\footnotetext{
${ }^{123}$ Kuppuswamy (n 32), 40-41.

${ }^{124}$ WHO Framework Convention on Tobacco Control (opened for signature 16 June 2003, entered into force 27 February 2005) 2302 UNTS 166.

125 International Health Regulations (2005), 79 UNTS 2509.

${ }^{126}$ World Health Organization, Pandemic Influenza Preparedness Framework for the Sharing of Influenza Viruses and Access to Vaccines and Other Benefits (World Health Organization, Geneva, 2011).

127 See WHO, 'WHO Priorities' < hwww.who.int/dg/priorities/en/> accessed 14 November 2018.

128 See WHO, 'Human Genomics in Global Health' <www.who.int/genomics/en/> accessed 8 November 2018.

${ }^{129}$ See WHO, ‘About WHO’s Human Genomics in Global Health Initiative’ <www.who.int/genomics/about/en/> accessed 8 November 2018.

${ }^{130}$ W Landman and U Schüklenk, 'UNESCO 'Declares' Universals on Bioethics and Human Rights: Many Unexpected Universal Truths Unearthed by UN body’ (2005) 5:3 Developing World Bioethics iii-vi; JR Williams, 'UNESCO's Proposed Declaration on Bioethics and Human Rights: A Bland Compromise' (2005) 5:3 Developing World Bioethics 210, 210-215.
} 
of having exceeded its mandate can stand when one considers how broad UNESCO's mandate is to begin with. Furthermore, within the UN, there are hardly other agencies that could claim the same level of experience at the intersection of sciences, ethics and human rights. UNESCO is the only UN agency specialized in sciences (both natural and human sciences) and has served for decades as a forum for philosophical discussion on cross-disciplinary issues. As it has been aptly said, "a conflict of competence between two or more UN agencies interested in this matter would be as absurd as a dispute between a philosopher and a doctor over the "ownership" of bioethics. Of course, bioethics does not belong in exclusivity to any of them. As it is by its very nature an interdisciplinary specialty, all related professions (and likewise, all related UN bodies) have the right — and the duty - to make their specific contribution to this emerging and complex domain". ${ }^{131}$ At the same time, as we also know, overlapping mandates and competences of international organizations increase the likelihood of fragmentation of international law opening the door for conflicting understandings of how the problems that arise in the field of human genome engineering and biomedicine more generally should be regulated.

As we said earlier, the WHO played a limited role until recently. Just days before this book went to the press, WHO's Director-General announced that its plan to put together an expert panel looking at international standard for human genome germline modification. "We will work with member states," Director-General Tetros stated, "to do everything we can to make sure of all issues - be it ethical, social, safety - before any manipulation is done." 132 We will see what comes out of this, although it is reasonable to assume that any such effort will take into account existing soft law standards in the field of international bioethics law that has been developed by UNESCO but with a focus on health-oriented issues and concerns.

As we saw, overlap between different branches of international law, such as between international bioethics law and international human rights law, is far from exceptional. It actually

\footnotetext{
${ }^{131}$ R Andorno, 'Global Bioethics at UNESCO: in Defense of the Universal Declaration on Bioethics and Human Rights' (2007) 33:3 Journal of Medical Ethics 150, 150-154.

${ }^{132} \mathrm{~S}$ Nebehay, 'WHO looks at standards in 'uncharted water' of gene editing' (Reuters, 2018)

$<$ www.reuters.com/article/us-china-health-who/who-looks-at-standards-in-uncharted-water-of-gene-editingidUSKBN1O227Q> accessed 13 December 2018.
} 
strengthens the whole construct of international human rights because the repetition of the same principles over and over helps solidifying norms into customary international law. UNESCO's and WHO's standard-setting activities operate at different levels. While UNESCO tends to produce general normative frameworks of a predominantly philosophical and legal nature, the WHO's guidelines are usually more technical and focused on specific health-related issues. ${ }^{133}$ However, although there is undoubtedly overlap between bioethics law and human rights law, there are also differences between the two branches when it comes to determining range of the human rights at stake in the field of biomedicine. We will revert to this later on. ${ }^{134}$

\section{3) The Organisation for Economic Co-operation and Development (OECD)}

The Organisation for Economic Co-operation and Development (OECD) is an intergovernmental organization whose aim is to stimulate economic progress and world trade. It comprises 36 high-income states that are committed to democracy and the market economy, a group that has sometimes been dubbed a "club of rich countries". ${ }^{135}$ Of the states surveyed in this book, only the People's Republic of China and Singapore are not members of it. ${ }^{136}$ It provides a platform to compare policy experiences, seeking answers to common problems, identify good practices and coordinate domestic and international policies of its members.

The OECD features a Working Party on Biotechnology, Nanotechnology and Converging Technologies that has focused on policy issues in emerging technology fields related to bio, nano and converging technologies, including gene editing. ${ }^{137}$ As far as norm-setting is concerned, so far the Working Party on Biotechnology has developed guidelines on human biobanks and genetic research databases; ${ }^{138}$ quality assurance of molecular genetic testing offered in a clinical

\footnotetext{
133 ibid.

${ }^{134}$ See in this Chapter Section III.5.

${ }^{135}$ The Economist explains, 'What is the OECD?' (The Economist, 6 July 2017) <www.economist.com/theeconomist-explains/2017/07/05/what-is-the-oecd $>$ accessed 8 November 2018.

${ }^{136}$ OECD, 'List of OECD Member countries - Ratification of the Convention on the OECD' (OECD, 19 July 2018)

$<$ www.oecd.org/about/membersandpartners/list-oecd-member-countries.htm> accessed 19 July 2018.

${ }^{137}$ OECD, 'Emerging technologies' < www.oecd.org/sti/emerging-tech/> accessed 8 November 2018.

${ }^{138}$ OECD, 'Guidelines for Human Biobanks and Genetic Research Databases (HBGRDs)'

$<$ www.oecd.org/sti/emerging-tech/guidelines-for-human-biobanks-and-genetic-research-databases.htm $>$ accessed 8 November 2018.
} 
Pre-editing version of the corresponding chapter in Andrea Boggio, Cesare P.R. Romano, Jessica Almqvist (eds.), Human Germline Genome Modification and the Right to Science: A Comparative Study of National Laws and Policies, Cambridge University Press, 2019 (ISBN: 9781108499873)

context; ${ }^{139}$ licensing of intellectual property rights that relate to genetic inventions used for the purpose of human health care; ${ }^{140}$ and policy papers on pharmacogenetics, ${ }^{141}$ and on biomarkers and targeted therapies. ${ }^{142}$

In 2015, the OECD Biotechnology Working Party launched the "Project on Gene Editing" to "produce a forum conducive to evidence-based discussion across countries on the many issues of shared concern... [and] to help guide policy at the national and international levels and promote - where appropriate - cooperative governance approaches". ${ }^{143}$ So far, the Project has produced a few working papers, including one on the governance of gene editing and advanced therapies. ${ }^{144}$

\section{4) Civil Society}

Finally, since the onset of the 'CRISPR revolution', several dozens of non-governmental organizations across the globe have issued 'statements', 'views', 'recommendations', and policy papers dealing specifically with germline genome engineering only. Carolyn Brokowski, of the Yale School of Medicine, reviewed 61 ethics reports and statements, crafted by more than 50 countries and organizations between 2015 and early 2018. ${ }^{145}$ The organizations include learned

\footnotetext{
${ }^{139}$ OECD, 'OECD Guidelines for Quality Assurance in Genetic Testing'< www.oecd.org/sti/emergingtech/oecdguidelinesforqualityassuranceingenetictesting.htm $>$ accessed 8 November 2018.

${ }^{140}$ OECD, 'Guidelines for the Licensing of Genetic Inventions' <www.oecd.org/sti/emergingtech/guidelinesforthelicensingofgeneticinventions.htm> accessed 8 November 2018.

${ }^{141}$ OECD, 'Pharmacogenetics: Opportunities and Challenges for Health Innovation' < www.oecd.org/sti/emergingtech/pharmacogeneticsopportunitiesandchallengesforhealthinnovation.htm> accessed 8 November 2018.

${ }^{142}$ OECD, 'Biomarkers and Targeted Therapies' < www.oecd.org/sti/emergingtech/biomarkersandtargetedtherapies.htm $>$ accessed 8 November 2018.

${ }^{143}$ See OECD, BNCT, 'Project on Gene Editing (Innovation Policy Platform)' $<$ www.innovationpolicyplatform.org/project-gene-editing-oecd-bnct> accessed 19 July 2018.

${ }^{144} \mathrm{H}$ Garden and D Winickoff, 'Gene editing for advanced therapies: Governance, policy and society', (OECD Science, Technology and Industry Working Papers, OECD Publishing, Paris, 2018).

${ }^{145}$ For a survey of 'ethical statements' on the matter, see, in general, C Brokowski, 'Do CRISPR Germline Ethics Statements Cut It?' (n 25), 115-125. Weeks before this book was being finalized, the Second International Summit of Genome Editing took place in Hong Kong (27-29 November 2018). The meeting, sponsored by the Academy of Science of Hong Kong, the UK Royal Society, the U.S. National Academy of Sciences and the Academy of Medicine, followed a meeting held in 2015 in Washington, D.C., to discuss the science, application, ethics, and governance of human genome editing. The Organizing Committee issued a statement on 29 November 2018. See The National Academies of Sciences, Engineering, and Medicine, Statement by the Organizing Committee of the Second International Summit on Human Genome Editing, (29 November 2018) $<$ http://www8.nationalacademies.org/onpinews/newsitem.aspx?RecordID=11282018b $>$ accessed 30 November 2018 .
} 
societies (e.g. the American and European Societies of Human Genetics, the European Society of Human Reproduction and Embryology, and the International Society for Stem Cell Research); bioethics organizations (e.g. the Nuffield Council in the United Kingdom, the Danish Council on Ethics, and the International Bioethics Committee of UNESCO); industry groups and organizations (e.g. the Biotechnology Innovation Organization and various genome-editing biotech companies); and political groups (e.g. the 2015 White House). ${ }^{146}$ Most reports and statements were produced by organizations from Europe and the United States, although groups from Canada, Latin America, New Zealand, Japan, China, Australia, and other international conglomerates also contributed. ${ }^{147}$

In her review, Brokowski notes that these statements vary considerably in both length and depth of analysis, from succinct, direct, and practical to expansive, indeterminate, nuanced, and philosophical. Positions range widely, too, but they can be clustered in groups. Overall, a majority of statements surveyed (54\%) expressly considered germline editing impermissible at the current time. ${ }^{148} \mathrm{~A}$ further $11 \%$ also consider germline editing impermissible currently, but are expressly open to the possibility of allowing it under certain conditions. ${ }^{149}$ In $30 \%$ of cases, the position is not expressly addressed or is ambiguous. ${ }^{150}$ Only $5 \%$ of the reports state an openness to further exploration. ${ }^{151}$

Overall, a large majority seems reluctant to proceed with heritable germline editing unless and until more were known about safety, risks, benefits, and efficacy and a broad societal consensus were achieved. Various categories of risk seem to outweigh any potential benefits, for now. Some favor a form of moratorium, ranging from broadly prohibiting "gene editing of human embryos or gametes which would result in the modification of the human genome" to more narrowly prohibiting "attempts to apply nuclear genome editing of the human germ line in clinical

\footnotetext{
146 Brokowski, Table 1, 117-119.

147 ibid.

148 ibid, Figure 3, 122.

149 ibid.

150 ibid.

151 ibid.
} 
practice." 152 A common concern is that editing might pose technical/mechanical obstacles, leading indefinitely to safety risks in the modified organism and future progeny, including inaccurate editing (off- and on-target effects), incomplete editing (mosaicism), efficiency challenges (success rate), and interference from unexpected and/ or poorly understood factors (e.g., epigenetic, immune, and environmental events; pleiotropy; and penetrance) resulting in unintended consequences. ${ }^{153}$ Other concerns included the potential return of eugenics, the misuse of this technology for human enhancement goals, and the exacerbation of social inequalities, along with a purported lack of compelling medical rationale justifying such interventions. ${ }^{154}$ Additionally, difficulties with obtaining actual informed consent, given the complexity surrounding the status of the human embryo and the potential effects lasting into numerous future generations, were highlighted. ${ }^{155}$ Many also seem to believe, correctly or incorrectly, that national and international laws already prohibit such modifications. ${ }^{156}$

Brokowski's survey of statements does not track whether there has been a shift of positions over time. It could not because of the novelty of CRISPR and the fact that it covers only the last three years. However, as science advances, uncertain, if not downright prohibitory legal frameworks notwithstanding, it is likely statements will gradually shift position as well, tracking public opinion sentiments. Indeed, as the German Ethics Council noted, there seems to have been a subtle, though important, shift in opinion about the permissibility of heritable genome editing: from "not allowed as long as the risks have not been clarified" to "allowed if the risks can be assessed more reliably". 157

As Brokowski noted, from a bioethics or legal perspective, many of these reports are limited. ${ }^{158}$ Some offer conclusions but lack significant support for them. At times, purported justifications for limitations lie on shaky logical and ethical foundations, and, although many of

\footnotetext{
152 ibid, 116.

153 ibid.

154 ibid.

155 ibid.

156 ibid.

${ }^{157}$ Deutscher Ethikrat, Germline Intervention in the Human Embryo: German Ethics Council Calls for Global Political Debate and International Regulation: Ad Hoc Recommendation (Berlin, 29 September 2017) 3.

${ }^{158}$ Brokowski (n 25), 116.
} 
these statements call for public engagement and open debates about risks, costs and benefits, few offer concrete ideas on how to organize those debates. Despite their value in raising questions and generating dialogue, it is unlikely that any single ethics report or position statement, now or in the future, could address all critical issues raised by heritable genome editing technology. Yet, even if one were to take an extreme view of international law, one that holds that it is only the official view of states, as articulated by their governments, that matters to determine opinio juris, it would be a serious mistake to dismiss them as irrelevant. Because of the high degree of technical and scientific complexity of human genome modification, governments would be hard pressed to justify departing from the recommendations of the learned societies in their country, and the consensus across boundaries.

\section{III) APPLICABLE INTERNATIONAL HUMAN RIGHTS STANDARDS}

While human rights are often acknowledged in 'soft law' bioethical instruments, such as the UNESCO declarations we just discussed, international human rights norms have not featured prominently in bioethical analyses, perhaps with the exception of the right to health. ${ }^{159}$ As a result, what a human rights approach to biomedical research, and germline engineering in particular, entails is still rather unclear. One of the goals of this book is to tackle this problem and advance our understanding how germline engineering and human rights intersect in this international framework.

We believe it is essential to take a fresh look at the complex relationship between the international bioethics instruments and international human rights law. Even if UNESCO stresses respect for human rights, its instruments are developed in parallel rather than in integration with international human rights law. The so called 'right to science' and the 'rights of science' in particular are referenced to but not fully incorporated in the UNESCO declarations and other international bioethics instruments. As we saw in the previous section, the contributions of the WHO and the OECD are still very limited. Although their work may contribute to the international

\footnotetext{
${ }^{159}$ See, e.g., R Andorno, Principles of International Biolaw: Seeking Common Ground at the Intersection of Bioethics and Human Rights (Bruylant, 2013); S Holm, The Law and Ethics of Medical Research: International Bioethics and Human Rights (Cavendish Publishing 2005).
} 
Pre-editing version of the corresponding chapter in Andrea Boggio, Cesare P.R. Romano, Jessica Almqvist (eds.), Human Germline Genome Modification and the Right to Science: A Comparative Study of National Laws and Policies, Cambridge University Press, 2019 (ISBN: 9781108499873)

protection of some human rights, none of them have an explicit and general mandate to advance human rights standard-setting in this field.

Our objective is not to give a comprehensive account of all international human rights that are touched by the scientific progress made on human germline genome modification. ${ }^{160}$ The list of human rights at play as a result of the recent advances made in the field of human germline modification is long, certainly too long for this book. It includes both civil and political rights (e.g. right to life; right to bodily integrity; right to privacy; right to academic freedom etc.) and economic, social and cultural rights (e.g. right to health; right to a family; right to benefit from progress in science and technology etc.), and their corresponding duties. It includes special protections of particularly vulnerable groups (e.g. children and women). Moreover, a comprehensive account of all the rights at play will need to consider both the global and regional regimes of human rights protection. Rather we focus on a set of rights that we believe have been set aside and ignored in the international efforts made so far to further governance of human germline modification, but which in our view should be brought to the center of the discussion: the so-called 'right to science' and the so-called 'rights of science'.

\section{1) The Right to Science and the Rights of Science: Origin and Development.}

The expression 'right to science' is commonly used to indicate one specific human right: the right to enjoy the benefits of scientific and technological progress and its applications. ${ }^{161}$ However, this is a cursory reading of what right to science means under international human rights law. In this section, we wish to develop a more detailed account of this right in the light of the human rights debates on the meaning and scope of this right. In addition, we believe that there is

\footnotetext{
${ }^{160}$ Albeit they are certainly relevant, we will not discuss here the right to health, reproductive rights and the right to integrity. These are complex rights that are touched by activities aimed at modifying the genome of human germline cells but cannot be given here the treatment they deserve. We suggest those interested in them to look further in current literature. E Riedel, 'Health, Right to, International Protection' (Max Planck Encyclopedia of Public International Law, last updated April 2011); J Gebhard and D Trimiño Mora, 'Reproductive Rights, International Regulation' (Max Planck Encyclopedia of Public International Law, last updated August 2013).

161 eg L Shaver, 'The Right to Science : Ensuring that Everyone Benefits from Scientific and Technological Progress' (2015) 4 European Journal of Human Rights 411, 411-430; A Chapman, 'Towards an Understanding of the Right to Enjoy the Benefits of Scientific Progress and Its Applications' (2009) 8:1 Journal of Human Rights 1. 136; M Mancisidor, 'Is There Such a Thing as a Human Right to Science in International Law?' (2015) 4:1 ESIL Reflections 1, 1-6.
} 
a need to distinguish the right to science from what we define as the 'rights of science'. We use the term 'rights of science' to indicate the set of rights and corresponding duties that concern scientific research and technological development, such as freedom of expression, academic freedom and the right to seek and disseminate knowledge, the right to associate, the right to work, the right to protection of the moral and material interests resulting from inventors' work, the duty states have to encourage scientific research and to facilitate cross-border cooperation and the like. While the right to science focuses on the right to benefit from scientific progress and its applications, the rights of science focus on the rights of scientists that enable them to conduct research, including in the field of biomedicine.

The roots of the rights of science run deep, arguably all the way to the early $1600 \mathrm{~s}$, with Francis Bacon and Galileo Galilei, and intertwine with other better known rights, such as the right to education and freedom of expression. Although the right to science is a considerably more recent idea, it is still one with lineage as old as any other internationally recognized human rights. Indeed, it was recognized first in the American Declaration of Human Rights, adopted at the Ninth International Conference of American States in Bogotá, Colombia, on 2 May $1948 .{ }^{162}$ The American Declaration preceded and inspired the proclamation of the same right in the Universal Declaration of Human Rights, adopted by the General Assembly of the United Nations on 10 December $1948 .{ }^{163}$

Article XIII of the American Declaration of Human Rights recites: "Every person has the right to take part in the cultural life of the community, to enjoy the arts, and to participate in the benefits that result from intellectual progress, especially scientific discoveries. He likewise has the right to the protection of his moral and material interests as regards his inventions or any literary, scientific or artistic works of which he is the author". Echoing the American Declaration, Article 27 of the Universal Declaration of Human Rights provides that: “(1) Everyone has the right freely to participate in the cultural life of the community, to enjoy the arts and to share in scientific

\footnotetext{
${ }^{162}$ American Declaration of the Rights and Duties of Man (adopted by the Ninth International Conference of American States, 1948) OAS Res XXX, reprinted in Basic Documents Pertaining to Human Rights in the InterAmerican System, OEA/Ser L V/II.82 Doc 6 Rev 1, at 17 (1992).

${ }^{163} \mathrm{See}$, in this chapter, Section I.3.
} 
advancement and its benefits. (2) Everyone has the right to the protection of the moral and material interests resulting from any scientific, literary or artistic production of which he is the author".

As we discussed earlier, recognition of the non-binding nature of mere declarations led the international community to start negotiations of a binding international human right treaty, but the division between East and West led to the adoption, instead, of twin treaties: one focused on civil and political rights (ICCPR) and the second on economic, social and cultural rights (ICESCR). ${ }^{164}$ Some 'rights of science' were included in the list of civil and political rights (e.g. freedom of expression, academic freedom and the right to seek and disseminate knowledge, the right to associate), while others were included in the list of economic, social and cultural rights. These include the right to work, the right to protection of the moral and material interests, the duty states have to encourage scientific research and to facilitate cross-border cooperation and the like, and also the right to health and the right to a family, which are key when discussing reproductive rights. The 'right to science' was included in the list of socio-economic rights, bundled together with a broader right called 'the right to culture'. Article 15 of the International Covenant on Economic, Social and Cultural Rights reads:

"1. The States Parties to the present Covenant recognize the right of everyone: (a) To take part in cultural life; (b) To enjoy the benefits of scientific progress and its applications; (c) To benefit from the protection of the moral and material interests resulting from any scientific, literary or artistic production of which he is the author.

2. The steps to be taken by the States Parties to the present Covenant to achieve the full realisation of this right shall include those necessary for the conservation, the development and the diffusion of science and culture.

3. The States Parties to the present Covenant undertake to respect the freedom indispensable for scientific research and creative activity.

164 ibid. 
Pre-editing version of the corresponding chapter in Andrea Boggio, Cesare P.R. Romano, Jessica Almqvist (eds.), Human Germline Genome Modification and the Right to Science: A Comparative Study of National Laws and Policies, Cambridge University Press, 2019 (ISBN: 9781108499873)

4. The States Parties to the present Covenant recognise the benefits to be derived from the encouragement and development of international contacts and co-operation in the scientific and cultural fields."

As it was discussed, the basic structure of the UN human rights regime, with a declaration and two separate instruments, each dedicated to a family of rights, was echoed in various regions across the globe. ${ }^{165}$ As a consequence, we can find the 'right to science' and the 'rights of science' also in various regional legal instruments. For instance, in the Americas, besides in the American Declaration, ${ }^{166}$ one can find elements of these rights in several articles of the Charter of the Organization of American States (1948), ${ }^{167}$ and in the Additional Protocol to the American Convention on Human Rights in the Area of Economic, Social and Cultural Rights ('Protocol of San Salvador'), which, echoing the Covenant, requires states to recognize the right of everyone 'to enjoy the benefits of scientific and technological progress' ${ }^{168}$ and the duty of states to 'extend among themselves the benefits of science and technology by encouraging the exchange and utilization of scientific and technological knowledge'. ${ }^{169}$

In Africa, the Constitutive Act of the African Union identifies scientific and technical cooperation as essential for meeting its goals, ${ }^{170}$ and the Protocol on the Rights of Women in Africa of the African Charter on Human and Peoples' Rights requires States to take specific measures to promote education and training for women, particularly in the fields of science and technology. ${ }^{171}$

In the Arab world, the Arab Charter on Human Rights recognizes the right of everyone "to take part in cultural life and to enjoy the benefits of scientific progress and its application”, together with the obligations of States to "respect the freedom of scientific research and creative activity,

\footnotetext{
165 ibid.

${ }^{166}$ American Declaration (n 164), art XIII.

${ }^{167}$ Charter of the Organization of American States (1948), 119 UNTS 3, arts 17, 30, 34.i, 38, 45, 47 and 51.

168 ICESCR, art 14.1.b.

169 Additional Protocol to the American Convention on Human Rights in the area of Economic, Social, and Cultural Rights (Protocol of San Salvador), OAS Treaty Series No 69, art 38.

${ }^{170}$ Constitutive Act of the African Union (adopted July 11, 2000, entered into force May 26, 2001) OAU Doc. $\mathrm{CAB} / \mathrm{LEG} / 23.15$, art 3.m.

${ }^{171}$ Maputo Protocol on the Rights of Women in Africa of the African Charter on Human and Peoples' Rights (signed 11 July 2003, entered into force 25 November 2005) CAB/LEG/66.6, , art. 12. 2.b.
} 
Pre-editing version of the corresponding chapter in Andrea Boggio, Cesare P.R. Romano, Jessica Almqvist (eds.), Human Germline Genome Modification and the Right to Science: A Comparative Study of National Laws and Policies, Cambridge University Press, 2019 (ISBN: 9781108499873)

... ensure the protection of moral and material interests resulting from scientific, literary and artistic production ... enhance cooperation at all levels, with the full participation of intellectuals and inventors and their organizations, in order to develop and implement recreational, cultural, artistic and scientific programs". ${ }^{172}$

Finally, in South East Asia, the ASEAN Human Rights Declaration provides that every person has "the right, individually or in association with others, to freely take part in cultural life, to enjoy the arts and the benefits of scientific progress and its applications and to benefit from the protection of the moral and material interests resulting from any scientific, literary or appropriate artistic production of which one is the author."173

Oddly, in Europe, there is no explicit reference to the right to science neither in the European Convention on Human Rights ${ }^{174}$ nor in the European Social Charter, ${ }^{175}$ the two most important human rights treaties in Europe. This is one of the great mysteries of international human rights law. However, at least for what concerns the European Union, this lacuna was partially filled in 2000 with the adoption of the Charter of Fundamental Rights of the European Union, which provides that scientific research shall be 'free of constraint. ${ }^{176}$

\section{2) From the Vanishing Point of International Human Rights Law to Front and}

\section{Center}

Although the right to science has been recognized under international law since 1948, until recently international, regional and national bodies, as well as human rights activists and scholars, have paid little attention to it. Writing in 1952, at the dawn of international human rights, Hersch Lauterpacht wrote "...if economic, social and cultural rights lie at the vanishing point of

\footnotetext{
172 Arab Charter on Human Rights (adopted 15 September 1994, entered into force 15 March 2008), reprinted in 12 Int'l Hum Rts Rep 893 (2005) art 42.

${ }^{173}$ Association of Southeast Asian Nations Human Rights Declaration (adopted at the 21st ASEAN Summit, Phnom Penh, Cambodia on 18 November 2012) art 32.

174 [European] Convention for the Protection of Human Rights and Fundamental Freedoms, ETS No. 5.

${ }^{175}$ European Social Charter (revised), ETS No. 163.

${ }^{176}$ Charter of Fundamental Rights of the European Union (proclaimed by the European Parliament on 7 December 2000 and entered into force in adapted wording with the date of the entry into force of the Lisbon Treaty on 7

December 2009) OJ C 326, (TEU) 391-407.
} 
international human rights law... then the question of the right to enjoy the benefits of scientific and technological progress and its applications lies at the vanishing point of economic, social and cultural rights". ${ }^{177}$ Science and human rights have had, for long, an uneasy relationship. When science is mentioned, it is more often as a threat to human rights than as a tool to enhance them and protect them. For instance, although the final act of the 1993 Vienna World Conference on Human Rights in Vienna, recognizes that "everyone has the right to enjoy the benefits of scientific progress and its applications", it also adds immediately after that "certain advances, notably in the biomedical and life sciences as well as in information technology, may have potentially adverse consequences for the integrity, dignity and human rights of the individual, and calls for international cooperation to ensure that human rights and dignity are fully respected in this area of universal concern." 178

The result of this diffidence and neglect is that our understanding of the normative content of the right to science - that is, what exactly are states' obligations - is not yet entirely settled. However, in the past two decades the right to science and the rights of science have gained a more prominent position in human rights debates in international fora, and progress towards a more complete understanding of these rights has been tangible.

At the global level, three developments are particularly significant. The first one, in 2009, is the adoption of the Venice Statement on the Right to Enjoy the Benefits of Scientific Progress and its Applications ('Venice Statement'), drafted under the auspices of UNESCO. ${ }^{179}$ The second one, also in 2009, is the appointment by the Human Rights Council of an Independent Expert in the field of Cultural Rights, whose mandate also includes the right to science. ${ }^{180}$ The third one took place in 2015 and is the mandate given by the Committee on Economic, Social and Cultural Rights, the expert body in charge of supervising implementation of the Covenant on Economic, Social and Cultural Rights, to two of its members, Mikel Mancisidor and Rodrigo Uprimny, to draft a 'general

\footnotetext{
${ }^{177}$ H Lauterpacht, 'The Problem of the Revision of the Law of War' (1952) 39 British Yearbook Int'1 L 139.

178 B Boutros-Ghali, World Conference on Human Rights: the Vienna Declaration and Programme of Action (New York, United Nations, Dept of Public Information, June 1993) I.11, para 3.

${ }^{179}$ UNESCO, Venice Statement on the Right to Enjoy the Benefits of Scientific Progress and Its Applications (2009).

${ }^{180}$ UN Human Rights Council (43rd Meeting) Resolution 10/23 (26 March 2009).
} 
comment' on the right to science. The eventual adoption by the Committee of the general comment, perhaps in 2019, will be the crowning moment of a decade-long process of normative development.

The Venice Statement is the outcome of a 2009 meeting sponsored by UNESCO aiming at "clarifying the normative content of the right to enjoy the benefits of scientific progress and its applications and generating a discussion among all relevant stakeholders with a view to enhance the implementation of this right". ${ }^{181}$ The Venice Statement makes two significant contributions. The first is spelling out the three duties that states parties to the Covenant on Economic, Social and Cultural Rights have, namely the duty to 'respect', to 'protect', and to 'fulfil'. 'Respecting' means guaranteeing the freedoms that are necessary to do science (e.g. autonomy, freedom of speech, freedom to assemble in professional societies and to collaborate, and to ensure science is not used to interfere with enjoyment of other human rights and freedoms). ${ }^{182}$ 'Protecting' means ensuring that science is not done by infringing upon the rights of anybody (e.g., research subjects, vulnerable populations, and so forth). ${ }^{183}$ 'Fulfilling' calls for a variety of strategies including monitoring harms arising from science, enhancing public engagement in decision-making about science and technology, ensuring access to benefits of scientific progress on a non-discriminatory basis, and developing science curricula at all levels of schooling. ${ }^{184}$ The second contribution made by the statement is pointing out that it is also incumbent upon non-governmental actors (e.g., scientific societies, for-profit entities, civil society) to contribute to the realization of the right to science. ${ }^{185}$.

The second significant development at the global level is the United Nations Human Rights Council's decision to give an Independent Expert a special mandate on cultural rights, including the right to science. The first appointee was Pakistani sociologist Farida Shaheed, and the current one is the Algerian-American law professor Karima Bennoune. In 2012, Shaheed released a report

\footnotetext{
181 Venice Statement (n 181), para 2.

182 ibid, para 14.

183 ibid, para 15.

184 ibid, para 16.

185 ibid, paras 25-27. The Statement touches also upon the issue of privatization of science and how it could conflict with the right to science. ibid, para 5.
} 
titled 'The Right to Enjoy the Benefits of Scientific Progress and its Applications. ${ }^{\text {' }}$ ' The report discusses the normative content, state obligations, and limitations of the right to science. With regard to the normative content, the report makes four contributions. First, it connects the right to science to the right to participate freely in the cultural life of the community as recognized by article 15 of the ICESCR. Article 15 entails the right to contribute to science (as knowledge producers) and enjoy opportunities to participate in decisions about science (as citizens). The report further maintains that the right should be enjoyed without discrimination. ${ }^{187}$ Second, it stresses the importance of freedom of research as a prerequisite of the enjoyment of the right to science. In fact, the ability to 'continuously engage in critical thinking about themselves and the world they inhabit, and ... the opportunity and wherewithal to interrogate, investigate and contribute new knowledge with ideas, expressions and innovative applications, regardless of frontiers' are a prerequisite for implementing both rights. ${ }^{188}$ Third, it connects the right to science to the concept of 'human dignity' to the extent that the right protects people's 'ability to aspire namely, to conceive of a better future that is not only desirable but attainable'. ${ }^{189}$ Aspirations, the Special Rapporteur noted, 'embody people's conceptions of elements deemed essential for a life with dignity. ${ }^{190}$ Fourth, it identifies links to other rights. In some cases, the right to science is enjoyed in conjunction with other rights, such as the right to seek information, to take part in the conduct of public affairs, to self-determination, to development, and to make informed decisions. ${ }^{191}$ The right to science is also a prerequisite for the realization of other rights, namely the right to food, health, water, housing, education, and a clean and healthy environment. ${ }^{192}$

The second part of the Report focuses on the normative content and related obligations of States. In it, the Special Rapporteur proposes a list of objectives that States must guarantee: access by all without discrimination; freedom of scientific research and opportunities for all to contribute

\footnotetext{
${ }^{186}$ F Shaheed, 'Report of the Special Rapporteur in the Field of Cultural Rights: The right to enjoy the benefits of scientific progress and its applications' (Presented at the twentieth session of the Human Rights Council, 14 May 2012) A/HRC/20/26.

187 ibid, s III.b.1.

188 ibid, para 18.

189 ibid, para 20.

190 ibid.

191 ibid, paras 21-22.

192 ibid, para 23.
} 
to the scientific enterprise, individual and collective participation in decision-making, and an environment that enables knowledge production and exchange. ${ }^{193}$

The third and last section of the Report discusses the limitations of the right to science. The Special Rapporteur pointed out that limitations certainly arise from the very same body of human rights law and thus, it must promote the general welfare and be proportionate to the objective. ${ }^{194}$ The regulation and protection of research subjects provides an example of a justifiable limitation of the right to science. ${ }^{195}$ The prohibition against subjecting a person without his free consent to medical or scientific experimentation is especially important. ${ }^{196}$ More controversially, the Rapporteur also cited the precautionary principle as an important guide for science and technology policies in the absence of scientific consent such that a certain sense of caution would not cause irreparable harm to the public or the environment. ${ }^{197}$

Finally, the third major development took place in 2015. The Committee on Economic, Social and Cultural Rights, the expert body in charge of supervising implementation of the Covenant on Economic, Social and Cultural Rights gave the mandate to two of its members, Mikel Mancisidor and Rodrigo Uprimny, to draft a 'general comment' on the right to science. The appointment of the two co-rapporteurs is a significant step because of the authority 'general comments' on human rights treaties have. Besides "assisting the States parties in fulfilling their reporting obligations," 198 general comments are commonly considered to be the official interpretation of a right on the part of the United Nations. ${ }^{199}$ The Committee is expected to adopt the general comment on the right to science by the end of 2019. While a draft is not yet available to the public, remarks made by the co-rapporteurs at various meetings have already provided sufficient insights on the direction the comment will take. The final text is expected to build upon

\footnotetext{
193 ibid, s III.B.

194 ibid, para 49.

195 ibid, para 51.

196 ICCPR (n 17) art 7: "No one shall be subjected without his free consent to medical or scientific experimentation"

${ }^{197}$ Report of the Special Rapporteur in the Field of Cultural Rights (n 186) para 50.

${ }^{198}$ Committee on Economic, Social and Cultural Rights, 'Report on the Third Session, Supplement No. 4' (1989) UN Doc E/1989/22, Annex III 'Introduction: the purpose of general comments'.

${ }^{199}$ L Grover and H Keller, 'General Comments of the Human Rights Committee and their Legitimacy' in L Grover, G Ulfstein and H Keller (eds), UN Human Rights Treaty Bodies: Law and Legitimacy (Cambridge University Press, Cambridge, UK, 2012) 116-198.
} 
Pre-editing version of the corresponding chapter in Andrea Boggio, Cesare P.R. Romano, Jessica Almqvist (eds.), Human Germline Genome Modification and the Right to Science: A Comparative Study of National Laws and Policies, Cambridge University Press, 2019 (ISBN: 9781108499873)

all that had been established so far, starting from the Venice statement, and solidify it into some clear guidance for states as to the contours of this right. We will further explore the normative content of the right to science and its implications for human germline modification in the conclusions of this book.

\section{3) Limits to the Right to Science and the Rights of Science}

Few international human rights can never be derogated and have no exceptions (e.g. the right not to be arbitrarily deprived of one's life, the right not to be subject to torture, cruel, inhuman or degrading treatment, the right not to be enslaved). Most are qualified, admit exceptions, and/or can be suspended legally, for various reasons and in various ways. The 'right to science' and the 'rights of science' are some of those. What exceptions and derogations are admissible in the case of each right depends on the wording of the specific legal instrument in which they have ben codified.

The Universal Declaration of Human Rights contains two main 'claw back' clauses. The first one is Article 29, which says: "(2) In the exercise of his rights and freedoms, everyone shall be subject only to such limitations as are determined by law solely for the purpose of securing due recognition and respect for the rights and freedoms of others and of meeting the just requirements

of morality, public order and the general welfare in a democratic society; (3) These rights and freedoms may in no case be exercised contrary to the purposes and principles of the United Nations". The second is Article 30, which says: "Nothing in this Declaration may be interpreted as implying for any State, group or person any right to engage in any activity or to perform any act aimed at the destruction of any of the rights and freedoms set forth herein". These are very broad provisions that over the decades have been used to justify all kinds of measures restrictive of freedoms, but that have also been used to protect democracy and human rights from their own excesses.

When states started negotiating the two covenants, they realized more precise limits were needed. Echoing Article 30 of the Universal Declaration, Article 5 of both the ICESCR and the ICCPR recite: "1. Nothing in the present Covenant may be interpreted as implying for any State, 
group or person any right to engage in any activity or to perform any act aimed at the destruction of any of the rights or freedoms recognized herein, or at their limitation to a greater extent than is provided for in the present Covenant". Both also add that no restriction upon or derogation from any of the fundamental human rights recognized or existing in any country in virtue of law, conventions, regulations or custom shall be admitted on the pretext that the covenants do not recognize those rights or that they recognize them to a lesser extent. ${ }^{200}$

Besides these common provisions, the ICCPR and the ICESCR then take a different approach to acceptable limitations to rights, largely due to the different nature of the rights protected in each instrument. The ICCPR contains a list of rights that can never be derogated. ${ }^{201}$ This includes the prohibition to subject a person to medical or scientific experimentation without consent. ${ }^{202}$ The others can be suspended "[i]n time of public emergency which threatens the life of the nation and the existence of which is officially proclaimed" ${ }^{203}$ or can be limited to "protect public safety, order, health, or morals or the fundamental rights and freedoms of others". These include the right to liberty of movement and freedom to choose residence and leave any country, including the own; $;{ }^{204}$ the right to a public trial; ${ }^{205}$ the right to manifest one's religion or beliefs and the rights of parents to ensure the religious and moral education of their children in conformity with their own convictions; ${ }^{206}$ the right of right of peaceful assembly; ${ }^{207}$ the right to freedom of association; ${ }^{208}$ and, of particular importance for scientists, the right to right to hold opinions without interference, to freedom of expression, including the freedom to seek, receive and impart information and ideas of all kinds, regardless of frontiers, through any media. ${ }^{209}$

The ICESCR steers clear of "public safety, order, health, or morals" arguments to justify limitations. Instead, rights under this Covenant "may subject ... only to such limitations as are

\footnotetext{
${ }^{200}$ ICESCR (n 18) art 5.2; ICCPR (n 17) art 5.2.

${ }^{201} \mathrm{ICCPR}$ (n 17) art 4.2.

202 ibid, art 7.

203 ibid, art 4.1.

204 ibid, art 12.

205 ibid, art 14.1 .

206 ibid, art 18.

$207 \mathrm{ibid}$, art 21.

208 ibid, art 22.

209 ibid, art 19.
} 
determined by law" and "only in so far as this may be compatible with the nature of these rights and solely for the purpose of promoting the general welfare in a democratic society". ${ }^{210}$ The distinction in the acceptable limitations to the rights protected in the two covenants is paramount because the 'right to science' and several of the 'rights of science' (e.g., the right to work, the right to protection of the moral and material interests, the duty states have to encourage scientific research and to facilitate cross-border cooperation and the like), the right to health and reproductive rights, which includes the right to choose when, how and how many children to have, are protected in the ICESCR, not the ICCPR. These rights can be limited only "for the purpose of promoting the general welfare in a democratic society" not for "public safety, order, health, or morals". Of course, one could argue that the two are the same. Certain limitations that, facially, are taken to protect "public safety, order, health, or morals" might also be "necessary to promote the general welfare in a democratic society", but the distinction is important and the burden of justifying restrictions to rights, to the international community and to their citizens, is on governments. Restrictions based on morality need to have broad support to be consistent with the goal of the promotion of welfare in a democratic society. Restrictions based on health must be supported with an explanation of how the balancing between the right to health of the individual and the right to health of the many has been achieved. Public safety can be invoked only if there is a concrete risk, scientifically proven, not just a speculative one.

\section{4) Dignity}

The duty to protect 'human dignity' features prominently in the already discussed soft law instruments relevant to human genome modification which form part of bioethics law, above all, the three UNESCO declarations. ${ }^{211}$ In this context, dignity is invoked particularly when pointing to certain practices "that may pose dangers to the integrity and dignity of the individual", ${ }^{212}$ and to justify restrictions, moratoria or bans. For instance, the preamble of UNESCO's 1997 Universal Declaration on Human Genome and Human Rights refers to dignity by recalling it is mentioned in

\footnotetext{
${ }^{210}$ ICESCR (n 18) art 4.

${ }^{211}$ See, in this chapter, Section II.1.

212 UN Commission on Human Rights, Commission on Human Rights Resolution 2003/69: Human Rights and Bioethics (E/CN.4/RES/2003/69, 25 April 2003) Preamble, para 4.
} 
Pre-editing version of the corresponding chapter in Andrea Boggio, Cesare P.R. Romano, Jessica Almqvist (eds.), Human Germline Genome Modification and the Right to Science: A Comparative Study of National Laws and Policies, Cambridge University Press, 2019 (ISBN: 9781108499873)

the preamble of its Constitution and in the preamble of the Universal Declaration of Human Rights. ${ }^{213}$ It also recognizes that "research on the human genome and the resulting applications open up vast prospects for progress in improving the health of individuals and of humankind as a whole, but emphasizing that such research should fully respect human dignity". ${ }^{214}$ Then, it starts with a section entitled "Human Dignity and the Human Genome", which proclaims: "The human genome underlies the fundamental unity of all members of the human family, as well as the recognition of their inherent dignity and diversity", ${ }^{215}$ and "[e]veryone has a right to respect for their dignity and for their rights regardless of their genetic characteristics". ${ }^{216}$ Paragraph $b$ of Article 2 of the same declaration provides more insight into the meaning of 'dignity': “... dignity makes it imperative not to reduce individuals to their genetic characteristics and to respect their uniqueness and diversity". The same concept is in essence repeated in Article $6,{ }^{217} 10,{ }^{218} 11,{ }^{219}$ 12.a, ${ }^{220} 15,{ }^{221}$ and $21 .{ }^{222}$ Notably, the 1997 declaration seems to single out "germline interventions" as an example of a possible violation of human dignity. Under Article 24, the International Bioethics Committee of UNESCO is asked to "give advice concerning the follow-up of this Declaration, in particular regarding the identification of practices that could be contrary to human dignity, such as germ-line interventions". ${ }^{223}$

${ }^{213} 1997$ Universal Declaration on Human Genome and Human Rights (n 31), first and fourth preambular paragraphs.

214 ibid, six preambular paragraph.

215 ibid, art 1.

216 ibid, art 2.a.

217 "No one shall be subjected to discrimination based on genetic characteristics that is intended to infringe or has the effect of infringing human rights, fundamental freedoms and human dignity". ibid, art 6.

218 "No research or research applications concerning the human genome, in particular in the fields of biology, genetics and medicine, should prevail over respect for the human rights, fundamental freedoms and human dignity of individuals or, where applicable, of groups of people". ibid, art 10.

219 "Practices which are contrary to human dignity, such as reproductive cloning of human beings, shall not be permitted". ibid, art 11.

220 "Benefits from advances in biology, genetics and medicine, concerning the human genome, shall be made available to all, with due regard for the dignity and human rights of each individual". ibid, art 12.a.

221 "States should take appropriate steps to provide the framework for the free exercise of research on the human genome with due regard for the principles ... to safeguard respect for ... human dignity". ibid art 15.

222 "States should take appropriate measures to encourage other forms of research, training and information dissemination conducive to raising the awareness of society and all of its members of their responsibilities regarding the fundamental issues relating to the defence of human dignity". ibid art 21.

${ }^{223}$ Emphasis added. 
Also the 2003 International Declaration on Human Genetic Data uses the expression "human rights, fundamental freedoms or human dignity" repeatedly to indicate the object of the duty of protection that states have. 'Dignity' is found in the preamble, and it is referenced in the description of the aim, ${ }^{224}$ prohibition of use of genetic data to infringe human dignity, ${ }^{225}$ and prohibition of acts contrary to dignity. 226

Likewise, the 2005 Universal Declaration on Bioethics and Human Rights refers to 'dignity' repeatedly. Besides the preamble, which echoes those of the two previous declarations, the stated aims of the declaration are, inter alia, "(c) to promote respect for human dignity and protect human rights ...; and (d) to recognize the importance of freedom of scientific research and the benefits derived from scientific and technological developments, while stressing the need for such research and developments... to respect human dignity, human rights and fundamental freedoms." 227 Article 3 declares at paragraph 1 that "[h]uman dignity, human rights and fundamental freedoms are to be fully respected", and paragraph 2 contains the corollary of the principle of human dignity: people should not simply become instruments for the benefit of science, because science is not an absolute, but only a means at the service of the human person. The duty to respect human dignity is echoed in Article $10,{ }^{228}$ as well as in the prohibitions of discrimination, ${ }^{229}$ and of acts contrary to human rights, fundamental freedoms and human dignity. ${ }^{230}$ Finally, although the declaration restates the importance of giving due regard to the importance of "cultural diversity and pluralism", those cannot be invoked "...to infringe upon human dignity, human rights and fundamental freedoms."231

\footnotetext{
${ }^{224}$ UNESCO, International Declaration on Human Genetic Data (n 63). Ensuring "the respect of human dignity and protection of human rights and fundamental freedoms in the collection, processing, use and storage of human genetic data", art 1.a.

225 ibid, art 7.a.

226 ibid, art 27.

${ }^{227}$ UNESCO, Universal Declaration on Bioethics and Human Rights (n 78) art 2.

228 "The fundamental equality of all human beings in dignity and rights is to be respected so that they are treated justly and equitably". ibid, art 10.

${ }^{229}$ Ibid, art 11.

230 ibid, art 28 .

231 ibid, art 12.
} 
Pre-editing version of the corresponding chapter in Andrea Boggio, Cesare P.R. Romano, Jessica Almqvist (eds.), Human Germline Genome Modification and the Right to Science: A Comparative Study of National Laws and Policies, Cambridge University Press, 2019 (ISBN: 9781108499873)

The Council of Europe included the word 'dignity' in the full title of the Oviedo Convention: "Convention for the Protection of Human Rights and Dignity of the Human Being with regard to the Application of Biology and Medicine". ${ }^{232}$ The Oviedo Convention envisages a very broad protection of human dignity. Article 1 postulates generally that “...parties ... shall protect the dignity and identity of all human beings". Dignity is also mentioned in the preamble, where it says: "the misuse of biology and medicine may lead to acts endangering human dignity".

Dignity is also invoked in general international instruments. ${ }^{233}$ The concept was first included in the preamble to the Charter of the United Nations, in $1945 .^{234}$ The second paragraph 'reaffirms faith ... in the dignity and worth of the human person'. This reference to dignity was taken up in the 'International Bill of Rights'. The preamble and Article 1 of the Universal Declaration of Human Rights proclaim: "[a]11 human beings are born free and equal in dignity and rights". ${ }^{235}$ Dignity is further mentioned in Articles 22 and 23, which both proclaim certain social rights. The preambles to the ICCPR ${ }^{236}$ and ICESCR ${ }^{237}$ affirm that the human rights guaranteed by the covenants 'derive from the inherent dignity of the human person'. The United Nations Millennium Declaration of the United Nations General Assembly mentions the principle of dignity several times. ${ }^{238}$ In particular, human dignity is recognized as a core value of the United Nations system. $^{239}$

Although, all these references to human dignity are not immediately legally binding, as they are either part of the non-binding preamble to a generally binding treaty or they are expressed in a resolution of the UN General Assembly, which has no directly binding effect, nearly all major

\footnotetext{
232 Convention for the Protection of Human Rights and Dignity of the Human Being with Regard to the Application of Biology and Medicine: Convention on Human Rights and Biomedicine (opened for signatures on 4 April 1997, entered into force 12 January 1999) ETS No. 164 (Oviedo Convention). On the Oviedo Convention, see in this book, Part 3, Section II, Chapter 6.

${ }^{233}$ See, in general, D Kretzmer and E Klein (eds) The Concept of Human Dignity in Human Rights Discourse (Kluwer The Hague 2002).

${ }^{234}$ United Nations, Charter of the United Nations, (entered into force 24 October 1945) 1 UNTS XVI.

${ }^{235}$ UDHR (n 11).

${ }^{236}$ ICCPR (n 17).

${ }^{237}$ ICESCR (n 18).

${ }^{238}$ United Nations Millennium Declaration (published 18 September 2000, UNGA Res 55/2) paras I.2, I.6, and VI. ${ }^{239}$ ibid.
} 
Pre-editing version of the corresponding chapter in Andrea Boggio, Cesare P.R. Romano, Jessica Almqvist (eds.), Human Germline Genome Modification and the Right to Science: A Comparative Study of National Laws and Policies, Cambridge University Press, 2019 (ISBN: 9781108499873)

general human rights instruments mention human dignity in their operative part, for example, how persons deprived of liberty should be treated, ${ }^{240}$ the aims of the right to education, ${ }^{241}$ what is required by the right to privacy, ${ }^{242}$ the limits to forced labor as a penalty, ${ }^{243}$ and the motive for prohibiting exploitation and degrading treatment. ${ }^{244}$ The only exception is the European Convention for the Protection of Human Rights and Fundamental Freedoms, where 'dignity' is nowhere to be found. ${ }^{245}$ However, this gap has been filled by the European Court of Human Rights, which has interpreted certain provisions of the Convention in the light of the concept of human dignity. ${ }^{246}$ Moreover, the concept was elevated to keystone of the whole European human rights edifice by the Charter of Fundamental Rights of the European Union, which solemnly starts by saying: "Human dignity is inviolable. It must be respected and protected". ${ }^{247}$

All in all, the term dignity seems to be used in general human rights instruments to encapsulate two different concepts. ${ }^{248}$ On the one hand, it is used in a 'formal sense', justifying the existence of human rights and decoupling them, not formally, but philosophically, from the requirement of state consent. Individuals have human rights because they have dignity that is

240 eg ICCPR (n 17) art 10.1; American Convention on Human Rights (adopted 21 November 1969, entered into force 18 July 1978) 1144 UNTS 123, art 5.2.

${ }^{241}$ ICESCR (n 18) art 13.1.

242 American Convention on Human Rights (n 240) art 11.1.

243 ibid, art 6.2 .

${ }^{244}$ African [Banjul] Charter on Human and Peoples' Rights (adopted 27 June 1981, entered into force 21 October 1986) 1520 UNTS 217, art 5.

${ }^{245}$ Convention for the Protection of Human Rights and Fundamental Freedoms, ETS No. 5 (European Convention on Human Rights, as amended) (ECHR). On the ECHR, see in this book Part 3, Section II, Chapter 6. See, in general, B Maurer and others, Le principe de respect de la dignité humaine et la convention européenne des droits de l'homme (Documentation Française, Science et technique de la démocratie, 1999).

246 J-P Costa, 'Human Dignity in the Jurisprudence of the European Court of Human Rights' in C McCrudden (ed), Understanding Human Dignity (OUP 2014) 393-402; A Oehling de los Reyes, 'The Human Dignity Concept in the Case Law of the European Court of Human Rights' in L Gordillo (ed), Constitutionalism of European Supranational Courts: Recent Developments and Challenges (Thomson Reuters 2015) 21-32. For a view on how international courts other than the European Court, have interpreted dignity, see: C McCrudden, 'Human Dignity and Judicial Interpretation of Human Rights' (2008) 19:4 European Journal of International Law 655, 655-724; P Carozza, 'Human Dignity and Judicial Interpretation of Human Rights: A Reply' (2008) 19:4 European Journal of International Law 931, 931-44.

${ }^{247}$ Charter of the Fundamental Rights of the European Union [2000] OJ C 364/1, art 1. On the Charter of Fundamental Rights of the EU, see, in this volume, Part 3, Section II, Chapter 6.

${ }^{248}$ N Petersen, 'Human Dignity, International Protection' (Max Planck Encyclopedia of Public International Law, last updated October 2012), paras 19 and 37; JA Frowein 'Human Dignity in International Law' in D Kretzmer and E Klein (eds) The Concept of Human Dignity in Human Rights Discourse (Kluwer The Hague 2002) 121-32. 
Pre-editing version of the corresponding chapter in Andrea Boggio, Cesare P.R. Romano, Jessica Almqvist (eds.), Human Germline Genome Modification and the Right to Science: A Comparative Study of National Laws and Policies, Cambridge University Press, 2019 (ISBN: 9781108499873 )

inherent to them, not because states have entered into treaties recognizing them. ${ }^{249}$ On the other hand, it is also used in a substantive sense as a legal guarantee assuring the respect of human beings and protecting them against humiliation and degradation. ${ }^{250}$ It also plays a "founding function" for international human rights law, ${ }^{251}$ demonstrated by several preambles to international human rights instruments such as the one of the UDHR, which invokes the "recognition of inherent dignity ... the foundation of freedom, justice and peace in the world". ${ }^{252}$

International bioethical law instruments seem to emphasize the importance of human dignity in a more powerful way than traditional human rights law. ${ }^{253}$ Indeed, in contrast to the background role assigned to human dignity in international human rights instruments, international bioethical law puts it at the foreground as the ultimate rationale for the norms relating to this discipline. ${ }^{254}$ In this context, dignity is not understood as an independent legal guarantee. It is rather an argument justifying the elaboration of special regulations, restrictive measures and, indeed, bans, in the field of bioethics. ${ }^{255}$

The use of the 'dignity' in relation to reproductive human cloning is a perfect illustration. The 1998 World Health Organization Resolution on Ethical, Scientific and Social Implications of

\footnotetext{
249 "This is particularly the case for art 5 of the African Charter on Human and Peoples' Rights, but also for the preamble of Protocol No 13 to the European Convention on Human Rights concerning the Abolition of the Death Penalty and the jurisprudence of the European Court of Human Rights". Petersen (n 248), para 19.

250 "On the other hand, it is also used in a substantive sense. This is particularly obvious for art 11.1 of the American Convention on Human Rights. In this context, dignity shall guarantee the respect of the human being and protect him against humiliation and degradation". ibid. On the foundational role played by dignity, see also, P Capps Human Dignity and the Foundations of International Law (Hart Oxford 2009); A Gewirth 'Human Dignity as the Basis of Rights' in MJ Meyer and WA Parent (eds) The Constitution of Rights: Human Dignity and American Values (Cornell University Press Ithaca 1992) 10-28; O Schachter 'Human Dignity as a Normative Concept' (1983) 77 American Journal of International Law 848, 848-854.

${ }^{251} \mathrm{~K}$ Dicke 'The Founding Function of Human Dignity in the Universal Declaration of Human Rights' in D Kretzmer and E Klein (eds) The Concept of Human Dignity in Human Rights Discourse (Kluwer The Hague 2002) 111-120.

${ }^{252}$ UDHR (n 11), first preambular paragraph.

${ }^{253}$ R Andorno, 'Global Bioethics at UNESCO: in Defense of the Universal Declaration on Bioethics and Human Rights' (2007) 33:3 Journal of Medical Ethics 150, 153.

${ }^{254} \mathrm{R}$ Andorno, 'La notion de dignité humaine est-elle superflue en bioéthique?' (2005) 16 Revue générale de droit médical 95, 95-102; J-S Gordon, 'Human Dignity, Human Rights, and Global Bioethics' in W Teays, J-S Gordon, A Dundes Renteln (eds), Global Bioethics and Human Rights: Contemporary Issues (Rowman \& Littlefield 2014) 68-91; D Beyleveld and R Brownsword, Human Dignity in Bioethics and Biolaw (Oxford: Oxford University Press, 2002); C Foster, Human Dignity in Bioethics and Law (Hart Oxford 2011).

${ }^{255}$ Petersen (n 248) para 23.
} 
Pre-editing version of the corresponding chapter in Andrea Boggio, Cesare P.R. Romano, Jessica Almqvist (eds.), Human Germline Genome Modification and the Right to Science: A Comparative Study of National Laws and Policies, Cambridge University Press, 2019 (ISBN: 9781108499873)

Cloning in Human Health recalls in its preamble 'its condemnation of human cloning for reproductive purposes as contrary to human dignity'. ${ }^{256}$ State representatives referred to human dignity during the negotiations on the International Convention against the Reproductive Cloning of Human Beings to justify a prohibition of cloning. ${ }^{257}$ However, they could not reach any consensus on the forms of cloning that were to be included in the ban. The compromise formula found for the UN General Assembly Resolution 59/280 on Human Cloning is the prohibition of 'all forms of human cloning inasmuch as they are incompatible with human dignity'. ${ }^{258}$

Some go as far as arguing that 'dignity' is part of customary international law or constitutes a 'general principle of international law'. ${ }^{259}$ Others argue that it is the legal foundation of international human rights law. ${ }^{260}$ Yet, some dismiss it as a useless notion; ${ }^{261}$ one that does not have an autonomous value since, in international human rights law, the term is always used in combination with other guarantees and prohibitions. ${ }^{262}$ As a matter of fact, its importance notwithstanding, no legal instrument contains an effective general guarantee of human dignity and none defines it. Not even the German Constitution, which enshrines the principle that " $t$ ] he dignity of man is inviolable' in Article 1.1, one of the few articles that cannot be changed, defines it. ${ }^{263}$ As it has been said, it seems that it is this very nature of the concept of dignity "that has allowed,

\footnotetext{
${ }^{256}$ World Health Organization, Resolution on the Ethical, Scientific and Social Implications of Cloning in Human Health, (WHA51/1998/REC/1) Preamble, para 1.

${ }^{257}$ United Nations General Assembly, Press Release: Ethical Issues Stressed as Legal Committee ContinuesDebate on two Draft Texts on Human Cloning (UN Doc. GA/L/3258, 22 October 2004).

${ }^{258}$ UN General Assembly Resolution 59/280 on Human Cloning (A/RES/59/280, 8 March 2005) para b. Emphasis added.

${ }^{259}$ Petersen (n 248), para 6.

${ }^{260}$ J Waldron, 'Is Dignity the Foundation of Human Rights?' (Public Law \& Legal Theory Research Paper Series Working Paper No 12-73, January 2013).

261 eg R Macklin, 'Dignity is a Useless Concept: It means no more than respect for persons or their autonomy' (2003) 327:7429 British Medical Journal 1419, 1419-1420.

262 On the uses and abuses of the concept of dignity in law, see, in general: E Hilgendorf, 'The Abuse of Human Dignity - Difficulties in Using the Human Dignity Topos Taking the Bio-Ethics Debate as an Example' in E Hilgendorf and M Kremnitzer (eds), Human Dignity and Criminal Law (Würzburg Conference on Human Dignity, Human Rights and Criminal Law in Israel and Germany, July 20-22 2015, Duncker \& Humblot, 2018) 39-60; J Weinrib, 'Human Dignity and its Critics' in G Jacobsohn and M Schor (eds) Comparative Constitutional Theory (Edward Elgar Pbl, 2018) 167-186; R Andorno, 'The Paradoxical Notion of Human Dignity' (2001) 78 Rivista Internazionale di Filosofia del Diritto, 151-68.

263 "Die Würde des Menschen ist unantastbar. Sie zu achten und zu schützen ist Verpflichtung aller staatlichen Gewalt." (Human dignity shall be inviolable. To respect and protect it shall be the duty of all state authority.) Grundgesetz für die Bundesrepublik Deutschland 1949.
} 
Pre-editing version of the corresponding chapter in Andrea Boggio, Cesare P.R. Romano, Jessica Almqvist (eds.), Human Germline Genome Modification and the Right to Science: A Comparative Study of National Laws and Policies, Cambridge University Press, 2019 (ISBN: 9781108499873)

on the one hand, human rights to receive such international acceptance as a theoretical enterprise and, on the other hand, has led the concept to be constantly challenged by different cultures worldwide." 264 Indeed, despite the centrality of 'dignity' to international law and public discourse, there does not seem to be yet an equally universal understanding of its meaning.

Defining 'dignity' is an enduring problem of philosophy. The Roman philosopher Cicero held dignitas (dignity) to be the distinctive characteristic of humans compared to animals. ${ }^{265}$ However, dignity was not common to all human beings nor inherent, but rather a feature that could be gained or lost and that was influenced by social rank and authority. Medieval Christian theology held humans had inherent dignity because they were a creature of, and the image of, God (imago dei). ${ }^{266}$ That is still part of the official doctrine of the Catholic Church. ${ }^{267}$ During Renaissance, philosophy tried to free dignity from these metaphysical restrictions. In the Oration on the Dignity of Man (Oratio de hominis dignitate), Giovanni Pico della Mirandola explained that it is the characteristic of human dignity that every human being may decide freely about their way of living. ${ }^{268}$ Immanuel Kant further elaborated the idea of 'dignity as autonomy' in the Metaphysics of Morals (Die Metaphysik der Sitten), attributing dignity to persons who are capable of reasoning and thus capable of autonomy and morality. ${ }^{269}$

In more recent times, Alan Gewirth, while sharing Kant's view that rights arise from dignity, focuses on the positive obligations that dignity imposes on humans, such as the moral requirement not only to avoid harming others but to actively assist one another in achieving and

\footnotetext{
${ }^{264}$ PA Rodriguez, 'Human Dignity as an Essentially Contested Concept' (2015) 23:2 Cambridge Review of International Affairs 3.

${ }^{265}$ M T Cicero, 'De Officiis' (Book I.XXX, Walter Miller trans, Heinemann 1928) paras 5-9, 106-113.

${ }^{266}$ S Moyn, Christian Human Rights (University of Pennsylvania Press, 2015); T Lowenthal, 'The Role of Dignity in Human Rights Theory: Constituent or Teleological' (2015) 18 Trinity College Law Review 56, 56-83.

${ }^{267}$ Vatican, Catechism of the Catholic Church, Part Three (Life in Christ), Section One (Man's Vocation Life in the Spirit), Chapter One (The Dignity of the Human Person), art 1 (Man: The Image of God).

${ }^{268}$ G Pico della Mirandola, Oratio de hominis dignitate, para 20, 117 (Francesco Borghesi and others (eds), Cambridge University Press 2012, 1486); C McCrudden, 'Human Dignity and Judicial Interpretation of Human Rights' (2008) 19 European Journal of International Law 655, 659.

${ }^{269}$ I Kant, Metaphysics of Morals, The Doctrine of Virtue (Mary Gregor trans, Cambridge University Press 1991, 1797) ss 11 and 38, 230-231, 255; C McCrudden, 'Human Dignity and Judicial Interpretation of Human Rights' (2008) 19 European Journal of International Law 655, 659-660.
} 
Pre-editing version of the corresponding chapter in Andrea Boggio, Cesare P.R. Romano, Jessica Almqvist (eds.), Human Germline Genome Modification and the Right to Science: A Comparative Study of National Laws and Policies, Cambridge University Press, 2019 (ISBN: 9781108499873)

maintaining a state of well-being. ${ }^{270}$ For Jeremy Waldron, the concept of dignity is both a principle of morality and a principle of law. Drawing from the insights about dignity primarily from law, he explains that the use of human dignity in constitutional and human rights law "can be understood as the attribution of a high legal rank or status to every human being." 271

\section{5) A Synthesis of Human Rights Principles Applicable to the Scientific Enterprise.}

As we discussed in Part II, there is not yet a binding international legal instrument dedicated to the regulation of human germline modification from bench to bedside. A reason for this is that there is no international consensus as to what a global regulatory framework for human germline engineering should look like. However, the discovery of CRISPR has spurred a new global conversation on this issue, as evidenced by the numerous ethics statements that have been published since 2015. This conversation could result in a consensus for a more solid global regulatory framework to emerge. While penning a shared framework for human germline engineering requires time, "[f]ortunately, many of the institutions needed to regulate [germline engineering already] exist". ${ }^{272}$ Amongst these 'institutions' there is the corpus of international human rights law that has been developed since the end of the Second World War. We believe that international human rights law must to be at the center of the global conversation towards the development of a shared framework for human germline modification; the whole of it, not just some select pieces and bits. International bioethics instruments, as developed mainly by UNESCO, provide a narrow and inadequate account of the range of human rights that must be taken into account in this global conversation. While that branch of international law gives attention to some human rights, such as the right to free and informed consent or the right not to be discriminated against, it neglects many others, including the right to health, reproductive rights, and the so-called 'right to science' and the 'rights of science'. Moreover, while these international human rights are

\footnotetext{
270 A Gewirth, Self-Fulfillment (1998) 85, 127, and 180; A Gewirth, The Community of Rights (1996) 31-44; A Gewirth, Reason and Morality (1978) 134-136, 209-210. On Gewirth's view of dignity, see: D Beyleveld, 'Human Dignity and Human Rights in Alan Gewirth's Moral Philosophy' in M Düwell and others (eds), The Cambridge Handbook of Human Dignity: Interdisciplinary Perspectives (Cambridge University Press 2014) 230-239.

271 J Waldron, 'Dignity, Rank, and Rights: The Tanner Lectures on Human Values' (University of California, Berkeley, 21-23 April 2009) 250.

${ }^{272}$ N H Evitt, S Mascharak and R B Altman, 'Human Germline CRISPR-Cas Modification: Toward a Regulatory Framework' (2015) 15 American Journal of Bioethics 25.
} 
contained in treaties that state parties are legally bound to respect, protect and fulfill, international bioethics law is almost entirely made of soft-law legal instruments, whose legal significance is considerably less clear.

We believe the 'right to science' and the 'rights of science' are critically important as they protect the basic interests not only of scientists to continue advancing scientific research in this field but also the interests of beneficiaries of the scientific progress made, including its applications, not least to prevent and cure genetic diseases. A more thorough analysis of how these rights come into play and can contribute to the emerging international regulatory framework will be presented in the conclusions of the book. ${ }^{273}$ Here, we want to highlight five key principles that we see as emergent from the integration of international bioethics law with international human right slaw, particularly the 'right to science' and the 'rights of science', and foundational to an international framework for human germline engineering. These principles are: freedom of research; benefit sharing; solidarity; respect for dignity; and the obligation to respect and to protect the rights and individual freedoms of others. It is important to note that, in respecting these principles, states must provide an enabling environment (i.e., laws, regulations, funding) "necessary for the conservation, the development and the diffusion of science" and "recognize the benefits of international contacts and co-operation in the scientific field". ${ }^{274}$ Also, the three UNESCO declarations reference international cooperation in various articles, often stressing the need to involve developing countries. ${ }^{275}$

\section{i) Freedom of Research}

The first principle that international instruments recognize is freedom of research. The ICESCR requires State parties to "respect the freedom indispensable for scientific research". 276

\footnotetext{
${ }^{273}$ Part 4, Chapter 22.

${ }^{274}$ ICESCR (n 18) art 15.4.

275 The 2005 UNESCO Universal Declaration on Bioethics and Human Rights (n 78) requires states to "foster international dissemination of scientific information and encourage the free flow and sharing of scientific and technological knowledge, [...] promote cultural and scientific cooperation and enter into bilateral and multilateral agreements enabling developing countries to build up their capacity to participate in generating and sharing scientific knowledge, the related know-how and the benefits thereof." art 3.1.

${ }^{276} \mathrm{ICESCR}$ (n 18) art 15.3.
} 
The three UNESCO declarations also call for respect of the freedom of research. The 1997 Universal Declaration on Human Genome and Human Rights state that freedom of research "is necessary for the progress of knowledge" and "is part of freedom of thought". ${ }^{277}$ The 2003 International Declaration on Human Genetic Data states that due consideration must be given to "freedom of thought and expression, including freedom of research." 278 The 2005 Declaration recognize "freedom of science and research" as the basis of "scientific and technological developments" 279 and "the importance of freedom of scientific research and the benefits derived from scientific and technological developments." 280 The 2015 report of the UNESCO International Bioethics Committee, entitled "Updating Its Reflection on the Human Genome and Human Rights", states that "freedom of research and freedom of individuals should not be inhibited by too many strict regulations" and that "basic research ... is not possible without the freedom of researchers". 281

Freedom of research is both individual and collective, as well as negative and positive. Individually, freedom entails the right of "everyone" to participate in the scientific enterprise. The pronoun "everyone" includes scientists, tissue donors and patients. This right must be protected along with other freedoms that scientists enjoy, including the right to intellectual property, to participate in learned societies and travel, and to academic freedom. Collectively, it is the right of scientists to govern the scientific enterprise, the right to 'self-regulation', as well as the right to an environment that enables "the conservation, the development, and the diffusion of science and culture" (i.e., right to policies that support science, to research funding and infrastructure), as codified in Article 15.2 of the ICESCR.

Self-regulation, which comprises customs, principles, norms and institutions that scientists have developed over centuries as a means to regulate their work, is paramount for two reasons. First, it is constitutive of the scientific enterprise. Scientists have set the epistemological parameters of what constitutes science and what knowledge is scientific. Any individual who

\footnotetext{
2771997 UNESCO Universal Declaration on Human Genome and Human Rights (n 31) art 12(b).

2782003 UNESCO International Declaration on Human Genetic Data (n 63) art 1.

2792005 UNESCO Universal Declaration on Bioethics and Human Rights (n 78) Preamble.

280 ibid, art 2.

${ }^{281}$ UNESCO, International Bioethics Committee, Updating Its Reflections, (n 109) paras 10 and 29.
} 
claims to "do science" must comply with the norms and institutions of the scientific enterprise. Scientific self-regulation sets the normative parameters of what constitutes science. Second, selfregulation ensures that science is carried out responsibly. ${ }^{282}$ Self-regulation includes adherence to the scientific method, timely communication and publication, refinement of results through replication and extension of the original work, peer review, data sharing, authorship, and training and supervision of associates and students. These norms apply by virtue of membership in the scientific community and require maintaining the integrity of the research process. Science cannot work without them. Ultimately, self-regulation is integral to freedom of research, if this is understood as a negative freedom that demand that governments not to interfere with the internal workings of science.

\section{ii) Benefit Sharing}

The second principle is benefit sharing. It is codified in the ICESCR, which requires State parties to "recognize the right of everyone to enjoy the benefits of scientific progress and its applications." ${ }^{283}$ Benefit sharing must be understood as the right both to the creation of benefits and to access the benefits. In the first sense, the right of "everyone to enjoy the benefits of scientific progress and its applications" means that governments have an obligation to use scientific knowledge in ways that are beneficial to everyone. In particular, there is a duty to transform basic or foundational knowledge into applications, whenever possible and unless there are legally valid reasons not to do so. The 2003 UNESCO Declaration embraces this concept of 'benefit sharing' when it provides that governments must ensure "access to medical care, provision of new diagnostics, facilities for new treatments or drugs stemming from the research, [and] support for health services. ${ }^{284}$ In the second sense, 'benefit sharing' means that benefits must be enjoyed by everyone, without any discrimination. The UNESCO 1997 Declaration captures this idea by stating that "benefits from advances in biology, genetics and medicine, concerning the human genome, shall be made available to all". Like freedom of research, benefit sharing is both a

\footnotetext{
${ }^{282}$ See, in general, Institute of Medicine, National Academy of Sciences and National Academy of Engineering, Responsible Science, Volume I: Ensuring the Integrity of the Research Process (The National Academies Press 1992).

${ }^{283}$ ICESCR (n 18) art 15.1.

2842003 UNESCO International Declaration on Human Genetic Data (n 63) art 19.
} 
Pre-editing version of the corresponding chapter in Andrea Boggio, Cesare P.R. Romano, Jessica Almqvist (eds.), Human Germline Genome Modification and the Right to Science: A Comparative Study of National Laws and Policies, Cambridge University Press, 2019 (ISBN: 9781108499873)

negative and a positive right. Governments must not prohibit the translation of scientific knowledge into applications (negative) and must take steps to ensure that scientific knowledge is translated into applications (positive). ${ }^{285}$

\section{iii) Solidarity}

The third principle is solidarity. While featuring prominently in the UNESCO declarations, this principle is not expressly mentioned in the ICESCR. ${ }^{286}$ This is mostly like due to historical reasons. Solidarity was not part of the human rights jargon when the ICESCR was adopted. Its first use is credited to Karel Vasak, who used the term 'solidarity rights' in an article written for the UNESCO Courier in 1977 to name the so-called third generation human rights, which include the rights to development, to peace, to a healthy environment, to share in the exploitation of the common heritage of mankind, to communication and humanitarian assistance. ${ }^{287}$ Even today the principle of solidarity remains ill-defined. Often, solidarity is linked to social justice. Discussing it in the context of germline engineering, Debra Mathews reads solidarity as a minimal obligation not to contribute to inequality and social division. ${ }^{288}$ Solidarity conveys the moral responsibility that arises from shared human vulnerabilities and entails contributing to institutions that protect vulnerable individuals. This meaning of solidarity finds support in the ICESCR and the principle of nondiscrimination. Under Article 2, the States Parties "undertake to guarantee that the rights enunciated in the present Covenant will be exercised without discrimination of any kind as to race, colour, sex, language, religion, political or other opinion, national or social origin, property, birth or other status." Solidarity may also convey the need to be spread risks and benefits evenly. This means inclusion of vulnerable populations. It can be also mean 'intergenerational equity', which demands that states to take into account the rights of future generations when undertaking activities that may affect them. Mulvihill and his colleagues of the International Human Genome Organisation Committee of Ethics, Law, and Society take solidarity in a different direction, closer to benefit sharing. According to these authors, the principle of solidarity requires to "recognize the

\footnotetext{
${ }^{285}$ ICESCR (n 18) art 15.2.

${ }^{286}$ However, the ICESCR contains several obligations regarding international cooperation. eg art 15.4, on scientific cooperation.

${ }^{287}$ K Vasak, ‘A 30-year struggle’ (UNESCO Courier, November 1977) 29.

${ }^{288}$ D J H Mathews, 'Solidarity in the Age of CRISPR' (2018) 1 The CRISPR Journal 261.
} 
opportunities to share benefits as a public good" and the need for "a continued broad debate, including issues of benefit sharing versus private commercialisation." ${ }^{289}$ In this sense, the normative dimensions of solidarity and benefit sharing overlap.

\section{iv) Respect for Human Dignity}

The fourth principle is respect for human dignity. As we saw, reference is included in the preamble of the ICESCR and repeated several times in the UNESCO declarations. ${ }^{290}$ However, as it was explained, "human dignity' is a contested concept, one over which there has never been and will probably never be a consensus. ${ }^{291}$ Its application to germline modifications depends on which view of 'dignity' one espouses. If one follows Christian theology, modifying the human genome can be construed as a departure from the creator's blue print, the imago dei, and, therefore, an assault on dignity. ${ }^{292}$ This view emphasizes the absolute worth of each human life (starting from conception), the sanctity of life. It also upholds the absolute character of the prohibition on scientific exploitation of human embryos, sometimes expressed in terms of need to protect 'human dignity'. ${ }^{293}$ This position implies not only that modifying the human genome can be an assault on dignity; it is also associated with the position that scientists must not interfere in the process from conception to birth of a new human being regardless of purpose for such interference.

However, if the meaning of dignity is limited to human dignity and not extended to early stages of human life, and is understood as personal autonomy, as Pico della Mirandola and Kant, and their followers to the present day did, or if 'dignity' is understood not only as a right but also as a duty, one to assist others in achieving and maintaining a state of well-being, then one could argue that human germline genome modification, if used to cure genetic diseases, actually fulfils human dignity.

\footnotetext{
${ }^{289} \mathrm{~J}$ Mulvihill and others, 'Ethical Issues of CRISPR Technology and Gene Editing Through the Lens of Solidarity' (2017) 122:1 British Medical Bulletin 17, 17-29.

${ }^{290}$ See, in this chapter, Section III.4.

${ }^{291}$ See in this chapter, Section III.4

292 ibid (n 266).

293 J Waldron, 'Dignity, Rank and Rights' (n 271) 222-224.
} 
Pre-editing version of the corresponding chapter in Andrea Boggio, Cesare P.R. Romano, Jessica Almqvist (eds.), Human Germline Genome Modification and the Right to Science: A Comparative Study of National Laws and Policies, Cambridge University Press, 2019 (ISBN: 9781108499873)

In international law, neither of the two views prevails over the other. There is no indication that States espouse in a majority either position. However, it is clear that an understanding of the concept of 'human dignity' that embraces one view to the detriment of the other cannot be considered an accurate reflection of the law as it (de lege lata).

v) Obligation to Respect and to Protect the Rights and Individual Freedoms of Others

The fifth principle is that everyone has an obligation to respect and to protect the rights and individual freedoms of others. This principle is codified in the ICESCR, whose Article 5 provides that: "Nothing in the present Covenant may be interpreted as implying for any State, group or person any right to engage in any activity or to perform any act aimed at the destruction of any of the rights or freedoms recognized herein, or at their limitation to a greater extent than is provided for in the present Covenant." As we saw earlier, the same is also found in the Universal Declaration of Human Rights and the Covenant on Civil and Political Rights. ${ }^{294}$ It is one of the core principles of international human rights law, together with the prohibition of discrimination. Thus, unsurprisingly, the principle is found also in all three UNESCO declarations. For instance, the 1997 Declaration provides that: "No research or research applications concerning the human genome, in particular in the fields of biology, genetics and medicine, should prevail over respect for the human rights, fundamental freedoms and human dignity of individuals or, where applicable, of groups of people". ${ }^{295}$

The rules protecting human subjects in research certainly fall with this category. They include the duty to assess risks and benefits of research before research can being, research oversight to ensure that rules are followed and that criteria are satisfied, and the requirement of obtaining the free and adequate informed consent of any human being participating in research. Research oversight is usually set up at the institutional level, with peers and administrators approving and overseeing research, or at the national level, with institutional regulators assessing

\footnotetext{
${ }^{294}$ See in this chapter, Section III.3.

2951997 UNESCO Universal Declaration on Human Genome and Human Rights (n 31) art 10.
} 
Pre-editing version of the corresponding chapter in Andrea Boggio, Cesare P.R. Romano, Jessica Almqvist (eds.), Human Germline Genome Modification and the Right to Science: A Comparative Study of National Laws and Policies, Cambridge University Press, 2019 (ISBN: 9781108499873)

safety and benefit of research and therapies. In some jurisdictions, both levels are present. Clearly, research oversight must always be consistent with the principle of freedom of research.

\section{vi) Other Limitations}

The rights recognized by the ICESCR are not absolute. As we discussed, the Covenant contemplates limitations on them. ${ }^{296}$ According to Article 4, limitations are compatible with the Covenant only when "determined by law" and "for the purpose of promoting the general welfare in a democratic society". ${ }^{297}$ In other words, limitations must not conflict with the minimum core content of the Covenant's rights. By restricting the purposes for which limitations may be imposed and the manner in which that may be done, the ICESCR ensures that the rights are still protected. In the context of the right to science, Article 4 strikes the balance between freedom of research and benefit sharing on one hand and limitations on the other in favor of the former. The burden of proof that freedom of research and benefit sharing must be limited and to what extent is on governments. Scientists should not be asked to prove what society could gain is they were given the freedom to do research.

\section{IV) CONCLUSIONS}

In this chapter, we reviewed the key elements of the larger international and transnational framework within which the national legal regimes of human germline genome modifications exist. The pillars of this framework are the Universal Declaration of Human Rights and the two Covenants, which collectively form the so-called 'International Bill of Rights'. The most important provisions of the 'International Bill of Rights' that are relevant to human germline genome modification are the so-called 'right to science' and the 'rights of science'. In addition to the provisions of the 'International Bill of Rights', the framework includes nonbinding soft law instruments, adopted by international and intergovernmental organizations, and 'statements', 'views', 'recommendations', and policy papers issued by non-governmental organizations. Among these, the three declarations adopted by UNESCO are paramount in articulating some of the

\footnotetext{
${ }^{296}$ See in this chapter, Section III.3.

${ }^{297}$ ICESCR (n 18) art 4.
} 
principles of the emerging international framework of regulating human germline engineering. The UNESCO declarations and other non-binding soft law instruments form a body of law called 'international bioethics law.' We argue that international bioethics law and its instruments provide a narrow and inadequate description of the range of human rights that must be taken into account in the conversation on the regulation of germline engineering. These instruments must be integrated with the broader international human rights law corpus. When the two bodies of law are integrated, five key principles emerge as foundations of the emerging regulatory framework: freedom of research; benefit sharing; solidarity; respect for dignity; and the obligation to respect and to protect the rights and individual freedoms of others. We will come back to discussing the emerging international framework with its core five principles in the final chapter of this book, after Part 3 where our colleagues will discuss the regulation of human germline genome modification in eighteen choses states. There, in the final chapter, we will present the basic features of a human rights framework for human germline engineering. 